\title{
Seyahat Acentelerinin Web Sitelerinin Betimsel Analizi ve Tüketici Değerlendirmesi
}

\author{
DOI: 10.26466/opus.522687 \\ * \\ Mehmet Yalçın* - Ozan Bahar** \\ * Öğr. Gör., Pamukkale Üniversitesi, Sosyal Bilimler M. Y.O., Kınıklı/Denizli/Türkiye \\ E-Posta: mehmetyalcin@pau.edu.tr ORCID: 0000-0003-2040-3424 \\ ** Prof. Dr., Muğla Üniversitesi, Turizm Fakültesi, Kötekli / Muğla / Türkiye \\ E-Posta: obahar@mu.edu.tr \\ ORCID: $0000-0003-3349-5479$
}

\section{Öz}

Bu çalışma internet ve iletişim araçlarının gelişmesiyle işletmelerin sanal vitrini haline gelmiş olan web sitelerin seyahat acenteleri tarafindan mevcut kullanım durumlarınn ortaya konulmasını, web sitelerinde kullanılan bileşenlerin tüketici bakış açısıyla değerlendirilmesi ve tüketici değerlendirmeleri ile mevcut durumun kıyaslanmasına yöneliktir. Bununla birlikte seyahat acentelerinin turizm pazarındaki konumu ve tüketicilerin bir web sitesinden ne bekledikleri hakkında sonuçlara ulaşmak amaçlanmıştır. Bunun için Türkiye'de yer alan 386 A grubu seyahat acentesinin web siteleri alan yazın taraması sonucunda ortaya çıkmış 6 ana ölçüt başlığı altında 47 bileşen ile betimsel analiz yöntemiyle incelenmiştir. Betimsel analizde kullanılan web site değerlendirme bileşenleri 742 internet kullanıcısı tarafindan değerlendirilmiş ve bulgular karşılaştırılmıştır. Araştırma sonucunda elde edilen bulgulara göre seyahat acentelerine ait web sitelerinin çevrimiçi alışverişte yetersiz kaldığı, sosyal medya araçlarını etkin kul-

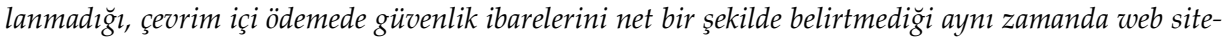
lerini pazarlama faaliyetlerinden çok bilgilendirme fonksiyonu için kullanıldığı ve tüketici beklentileri ile mevcut web sitelerinin örtüşmediği görülmüş̧ür.

Anahtar Kelimeler: Seyahat Acenteleri, Internet, Web Siteleri, Turizm Pazarlaması 


\title{
Descriptive Analysis and Consumer Evaluation of Travel Agencies Websites
}

\begin{abstract}
This study aims to reveal the current usage status of the travel agencies web sites that have become the virtual showcase of the enterprises with the development of internet and communication tools, The evaluation of the components used in the websites from a consumer point of view and the comparison of consumer assessments and the current situation. However, it is aimed to reach the results of travel agencies in the tourism market and what consumers expect from a website. For this, 386 travel agencies web sites located in Turkey with descriptive analysis were researched with 47 components under 6 main criteria. The web site evaluation components used in the descriptive analysis were evaluated by 742 internet users and the results were compared. According to the findings of the research, it is seen that web sites of travel agencies are inadequate in online shopping, do not use social media tools effectively, and do not explicitly specify security phrases on online payments. At the same time they are used for information functions rather than marketing activities, and consumer expectations and existing websites do not overlap.
\end{abstract}

Keywords Travel Agencies, Internet, Web Sites, Tourism Marketing 


\section{Giriş}

21. yüzyılda dünya ekonomisinde önemi artan ve hizmet sektörü içinde yer alan turizm hızla gelişen sektörler arasında yer almaktadır. Dünya genelindeki teknolojik gelişme ile tüketim ve tüketici tercihlerindeki farkl1laşma turizm sektörünün bu değişime daha hızlı adapte olmasını ve değişim karşısında dinamik olmasını gerektirmektedir (Bahar ve Kozak, 2008). Bundan dolayı turizm faaliyetlerinin, ürün-hizmet yönetimi ve pazarlanması için özel bir çaba gerekli olmaktadır.

Turizm sektöründe bilişim, iletişim ve internet teknolojisinden nasıl ve ne ölçüde yararlanıldığı, söz konusu teknoloji alanlardaki gelişmelerin turizm sektörü ve turizm pazarlaması üzerinde ne gibi etkilerinin olduğu, son yıllarda turizm pazarlaması araştırmalarında üzerinde araştırma yapılan, makaleler yazılan ve tezler hazırlanan önemli bir konu niteliğindedir. Bilgi ve iletişim teknolojilerinin kısa zaman içerindeki hızlı gelişimi ve değişimi göz önüne alındığında bu çalışmaların güncellenmesi ve geliştirilmesi ihtiyacı ön plana çıkmaktadır.

Teknoloji alanındaki gelişmeler ve bu gelişmelerin özellikle iletişim kanallarına olan etkisi küreselleşme olgusu içerisinde post modern anlayışla birleşerek pazarlama stratejilerinde yeni akımları beraberinde getirmektedir. İnternet kullanımı ve web siteleri sayesinde gün geçtikçe ön plana ç1kan elektronik pazarlama bu yeni akım içerisinde pazarlama kavramını başka bir boyutla ele alınması gerekliliğini ön plana çıkarmıştır. Dinamik yapısı ve sürekli etkileşimli iş anlayışına sahip seyahat acenteleri tüketicilerini yakından takip etmek zorunda olduğu için bu yeniliklere ayak uydurmaya çalışmakta ve çeşitli hizmetlerinin web ortamında sunulmasını desteklemektedir. Fakat iletişim hızının artması, internet kullanımına ve web sitelerine kolay erişim, rekabeti arttırmış aynı zamanda elektronik ortamda farklılık yaratmayı da gerekli hale getirmiştir. Dolayısıyla web sitelerin tasarımından sunumuna kadar tüketicilerin ihtiyaç, istek ve taleplerine göre şekillenmiş olması rekabet için gerekli bir gösterge olarak ortaya çımaktadır. Bu doğrultuda yapılan bu çalışmada Türkiye'de faaliyet gösteren A sınıfı seyahat acentelerinin web siteleri betimsel analiz ile incelenerek mevcut durumlarını ortaya çıkarmak ve tüketici değerlendirmeleri ile Türkiye'de faaliyet gösteren A sınıfı seyahat acentelerinin günümüz gelişen teknoloji döneminde tüketicilere web siteleri üzerinden 
hangi ölçüde hizmet verdiğinin anlaşılması amaçlanmıştır. Web sitesi değerlendirme ile ilgili literatür kapsamında birçok çalışma yapıldığı görülmektedir. Geçmişte yapılan çalışmalar incelendiğinde çalışmaların daha çok destinasyon ve konaklama işletmelerinin web siteleri üzerinde yoğunlaştı̆̆ı görülmektedir. Türkiye'de A sınıfı seyahat acenteleri üzerinde hem betimsel analiz hem de tüketici değerlendirmesi ile kıyaslama yapılarak çalışılan benzer bir araştırmanın olmayışı bu çalışmanın özgünlüğünü ortaya koymaktadır.

\section{Literatür Taraması}

İnternetin pazarlama içerisindeki yeri ve önemi gün geçtikte artmaktadır. Tüketici ile ilişkisel ve etkileşimli pazarlama imkânı sağlayan internet sayesinde işletmelerin ürün ve hizmetleri tüketici ile tek bir platformda buluşmaktadır. İnternetin sınırsız bir bilgi kaynağı olduğu da düşünüldügünde tüketici sadece ürünü satın almak için değil, satın alma kararını da kesinleştirebilmek için internetten bilgi edinme ve ürünü inceleme yoluna gidebilmektedir. Geleneksel pazarlama içerinde önemli olan fiziki varlık, coğrafi alan, yakınlık gibi unsurlar internet kullanımının artması ile önemini yitirmeye başlamış, geleneksel pazarlama karması bileşenleri farklı boyutlara ulaşmıştır (Akar, 2010, s.204). Özellikle dünya genelinde geçmiş yıllara göre artan internet kullanımı ve internetin birçok teknolojik alet ile bütünleşmesi modern pazarlama içerisinde internetin ne kadar önemli olduğunu kanıtlar niteliktedir. Tablo 1'de dünya nüfusunun internet kullanım oranı gösterilmektedir.

Tablo 1'e göre yaklaşık 7,7 milyar olan dünya nüfusunun 4,2 milyarı $(\% 54,4)$ internet kullanıcısı olarak görülmektedir. Dünya nüfusunun yarısindan daha fazlası herhangi bir yolla internete erişebilmektedir. Bu sayının ilerleyen yıllarda teknolojinin gelişmesine paralel olarak artması düşünülmektedir. Dünya nüfusunun internet kullanıcı sayılarında hem nüfus yoğunluğu olarak hem de internet kullanıcı sayısı bakımından Asya kıtası gelmektedir. Özellikle Doğu Asya ileri teknoloji üretiminde ve ihracatında dünya genelinde oldukça önemli bir konuma sahiptir. Bunun yanında Afrika kıtasının internet kullanım oranının nüfus yoğunluğuna rağmen diğer kıtalara göre daha az olduğu görülürken nüfus-internet kullanımı oranında Avrupa \%85,2 ile Kuzey Amerika ise \%95 internet kullanım 
oranı ile ilk sırada yer almaktadır. Bu bilgiden hareketle Avrupa ve Kuzey Amerika şehirlerinde yaşayan insanlar için internet kullanımının pazarlama için değerlendirildiğinde işletmeler ve tüketiciler için çok daha önemli bir konumda olduğu anlaşılabilir.

Tablo 1. Dünya İternet Kullanıcıları ve 2018 Nüfus Ístatistikleri(Internetworldstats, 2018)

\begin{tabular}{lrrrrr}
\hline \multicolumn{6}{c}{ Dünya İnternet Kullanıcıları ve 2018 Nüfus İstatistikleri } \\
\hline $\begin{array}{l}\text { Bölge- } \\
\text { ler }\end{array}$ & $\begin{array}{r}\text { Nüfus (2018 } \\
\text { Tahmini) }\end{array}$ & $\begin{array}{r}\text { Nüfusun } \\
\text { \% Dağ1- } \\
\text { limı }\end{array}$ & $\begin{array}{r}\text { Internet } \\
\text { Kullanıcıları }\end{array}$ & $\begin{array}{r}\text { İnternet/ } \\
\text { Nüfus \% }\end{array}$ & $\begin{array}{r}\text { Büyüme } \\
\text { (2000- } \\
\mathbf{2 0 1 8}\end{array}$ \\
\hline Africa & $1,287,914,329$ & $\% 16.9$ & $453,329,534$ & $\% 35.2$ & $\%, 941$ \\
\hline Asia & $4,207,588,157$ & $\% 55.1$ & $2,023,630,194$ & $\% 48.1$ & $\% 1,670$ \\
\hline Europe & $827,650,849$ & $\% 10.8$ & $704,833,752$ & $\% 85.2$ & $\% 570$ \\
\hline $\begin{array}{l}\text { Latin Ame- } \\
\text { rica/Caribean }\end{array}$ & $652,047,996$ & $8.5 \%$ & $437,001,277$ & $\% 67.0$ & $\% 2,318$ \\
\hline $\begin{array}{l}\text { Middle } \\
\text { East }\end{array}$ & $254,438,981$ & $3.3 \%$ & $164,037,259$ & $\% 64.5$ & $\% 4,893$ \\
\hline $\begin{array}{l}\text { North } \\
\text { Amer- } \\
\text { rica }\end{array}$ & $363,844,662$ & $4.8 \%$ & $345,660,847$ & $\% 95.0$ & $219 \%$ \\
\hline $\begin{array}{l}\text { Ocea- } \\
\text { nia/ }\end{array}$ & $41,273,454$ & $0.6 \%$ & $28,439,277$ & $\% 68.9$ & $273 \%$ \\
$\begin{array}{l}\text { Austra- } \\
\text { lia }\end{array}$ & $\mathbf{7 , 6 3 4 , 7 5 8 , 4 2 8}$ & $\mathbf{1 0 0 . 0} \%$ & $\mathbf{4 , 1 5 6 , 9 3 2 , 1 4 0}$ & $\% 54.4$ & $\mathbf{1 , 0 5 2} \%$ \\
\hline $\begin{array}{l}\text { Toplam } \\
\text { Nüfus }\end{array}$ & & & & & \\
\hline
\end{tabular}

Teknolojinin her alanda kullanılıyor olması şüphesiz ki insan yaşamını kolaylaştırmıştır. Özellikle internet dünyanın en önemli iletişim, iş yapış şekli ve bilgi alma kaynağı haline gelmiş ve kullanıcı sayısı bakımından büyük bir boyuta ulaşmıştır. Seyahat işletmeleri, internet teknolojisini ilk benimseyen ve bu teknolojiyi uygulamaya aktaran iş kollarından biri olmuştur. 1993 yılında ticari olarak kullanılmaya başlayan internetin çok daha öncesinde internet mantığına benzer bir iletişim ağı kullanan seyahat acenteleri havayollarının geliştirmiş oldukları sistemleri 1970'li yıllardan bu yana kullanmaktadır (Öğüt, Güleş ve Çetinkaya, 2003, s.260). Buradan hareketle Buhalis (1998, s.410), seyahat acentelerinde bilgi ve iletişim teknolojilerinin gelişimini aşağıdaki gibi açıklamıştır: 
- 1970 'li yıllarda bilgisayarlı merkezi rezervasyon sistemleri (CRS) kullanılmaya başlamıştır.

- $\quad 1980$ 'li yıllarda global dağıtım sistemleri (GDS) oluşmuştur.

- 1990 'lı yıllarda internet kullanımı yaygınlaşmıştır.

- İnternet kullanımının artması ile elektronik ticaret ortaya çıkmış yaygın bir biçimde kullanılmaya başlanmıştır.

Seyahat acentelerinde internet kullanım alanı olarak büyük oranda yapılan konaklama rezervasyonları, paket tur ve uçak bileti satışları karşımıza çıkmaktadır. 1980'li yıllarda American Airlines Sabre adını verdiği bu sistemi geliştirerek büyük bir pazar payı ve rekabet avantajı sağlamış, rezervasyon sistemlerinin hızlı gelişme ve genişlemesine katkıda bulunarak global dağıtım sistemin oluşmasını sağlamıştır (Arıkan ve Ahipaşaoğlu, 2005, s.180). Nitekim Galileo, Amadeus, Sabre, Worldspan gibi sistemler global dağıtım sistemlerine örnek teşkil etmektedir (Buhalis, 1998). Global dağıtım sistemleri, araç kiralama, otel rezervasyonları ve tren rezervasyonları gibi zamanla çeşitlenmeye başlamış, günümüzde rekabet avantajı ve verimliliği arttırarak seyahat acentelerini daha çekici kılmaktadır (Arıkan ve Ahipaşaoğlu, 2005, s.181). CRS ve GDS gibi uygulamaların yanında tüketici ara yüzü ile bakıldığında karşımıza "www", "w3" gibi isimlerle çıkan web platformu ya da web siteleri çıkmaktadır.

Modern pazarlama içerisine artık çok önemli bir yere sahip olan internet ve dijital teknolojiler geleneksel pazarlamanın tek yönlü iletişimine karşı, iki yönlü iletişim sistemini geliştirmiş, bu sayede pazarlamanın her aşamasında işletmenin beklediği mesajları kolay yoldan, hızlı bir şekilde iletmesine imkân sağlamıştır (Webster, 1996). Ainscough ve Luckett (1996, s.41) web üzerinden yapılan pazarlamayı dört kategoride toplamıştır. Dört kategori bir birinden bağımsız kullanılabileceği gibi hepsi bir anda pazarlama amaçlı olarak da kullanılabilir.

- Etkileşimli Broşür: Web sitesi üzerinde etkileşimli broşürlerde genellikle yazılı formlardan oluşan ve kare içerisinde görüntülü, sesli ve etkileşimli reklamları içermektedir.

- Bilgi Takası: Müş̧teriler ve araştırmacıların bilgi takası ortamıdır. Çevrimiçi ürün hakkında sorulan sorulara ve cevaplarına ulaşılabilir. Bunun yanında web siteleri üzerinden sanal toplantılar ve tartışma grupları oluşmak da mümkündür. 
- Sanal Vitrin: Sanal vitrin ile müşteriler web sitesi üzerinden ürünleri inceleyebilmektedir. Web sitesi üzerinden bir şirketin büyüklüğünü anlayabilmek oldukça zordur. Büyük köklü fiziksel dağ1tımı olan şirketler web sitesi üzerinden direk satışlarda küçük bir firmaya dönüşebilir. Web sitesi üzerinden satışlarda ödeme ciddi bir sorun olabilir.

- Müşteri Hizmetleri Aracı: Web siteleri müşteriye 24 saat ayrıntılı cevap verecek şekilde yapılabilir. Nitekim web sitesinde sıkça sorulan sorular (SSS) kısmı da bulunmaktadır. Müşteri bu sayede tahminde bulunabilir ve yine web sitesi üzerinden çevrimiçi yardım alabilir.

İnternet teknolojisi ticari kullanım için büyük bir potansiyele sahiptir. Web sitesi ise bu potansiyel içinde en önemli araçlardan birisidir (Cheung ve Huang, 2002, s.377). Web sitesi içerisinde birden fazla bileşeni barındırmaktadır. Bu nedenden bir web sitesi değerlendirilirken birden fazla bileşeni incelemek gerekmektedir. Kullanıcı çeşitliliği ile özelliklerinin farklı olması web sitesi değerlendirmede önemli bir sorun olabilmektedir. Bir web sitesinin tasarımı kavramsal, işlevsel ve estetik olarak ahenk içerisinde olmayı gerektirir. Bunun için ilk adım bilgi yapısının yeterli, eksiksiz ve kullanıcının beklentisine yönelik planın yapılmasıdır. İkinci adım ise uygun bir iletişim stratejisi ile görünümün tasarlanmasıdır (Marsico ve Levialdi, 2003). December (1994, s.13) bir web sitesinin en önemli unsurlarından biri olarak web sitesinde yer alan bilgi kalitesi üzerinde durmuştur. Bilginin sürekli güncel ve müşteri ihtiyaçlarına yönelik olması gerektiğini ve web sitesi üzerindeki bilginin kalitesini oluşturan etmenlerin doğruluk, erişilebilirlik, kullanılabilirlik, anlaşılabilirlik ve anlamlılık olduğunu aktarmıştır. Cox ve Dale (2001) web site tasarımı ve kullanımı ile ilgili olarak bir web sitesinin anahtar unsurlarını web sitesinin amaca yönelik olup olmadığına, tasarım unsurlarına, ulaşılabilirlik ve hızına, web sitesinin içeriğine, müşteriye yönelik hizmet ve iletişimi olarak aktarmıştır. Perdure (2001) müşteri deneyimlerini dikkate alarak yaptığı araştırmasında web site değerlendirme unsurları hızlı ve kaliteli web sitesi erişimi, kolay yönlendirme (navigasyon), web sitesinin görsel çekiciliği, bilgi içeriğinin kalitesi olarak dört ana başlık halinde sunmuştur. Liu ve Huang (2005) ise web sitelerinde yer alan bilgilendirmelerin güvenilirliği ile ilgili olarak altı farklı değerlendirme boyutunu ele almaktadır. 
Web sitesinin kaynağının erişilebilir olması, sayfada yer alan içerik bilgilerinin tam olması, web sayfasının görsel olarak bir bütünlük içermesi, içeriğin doğru ve güvenilir olması ve web sayfasına erişimin hızlı bir şekilde gerçekleşmesi ele alınan boyutlar arasındadır. Zafiropoulos ve Vrana (2006) otel web siteleri üzerine yaptığı değerlendirmede ölçüt olarak imkânlar, müşteri iletişimi, rezervasyon ve fiyat bilgilerini, çevresel faktörleri, web site yönetimi ve şirket yapısını almıştır. Zrivan, Glezer ve Avni (2006) ticari web sitelerinin müşteri memnuniyeti için yaptığı değerlendirmede web sitelerinin sınıflandırılması, müşteri temelli dizaynı, müşteri memnuniyeti unsurları ve web sitelerinin kullanılabilirliği başlıklarını ölçüt almıştır. Bu başlıklar altında kolay kullanılabilirlik, yönlendirme, ticari ve çevrimiçi alışveriş imkânları, güncellik, performans ve aranabilirlik gibi alt başlıkları web site değerlendirme için kullanmıştır. Chan ve Law (2006) web sitelerinin kaliteli bir tasarım açısından incelenmesinde web sitesinin kullanılabilirliği, ara yüz çekiciliği, bilgilendirme, yönlendirme kolaylığı ve kullanıcı dostu olmak üzere beş temel başlık üzerinde durmuştur. Dündar, Ecer ve Özdemir (2007) sanal mağazacılıkta önde gelen dört web sitesi değerlendirmesinde tasarım, bilgi zenginliği, müşteri hizmetleri ve ürün çeşitliği ölçütlerini temel almıştır. Park, Gretzel ve Sırakaya (2007) çevrimiçi seyahat acentelerinde web sitesi kalitesini kolay kullanım, bilgi ve içerik, potansiyel kullanım, cevaplanabilirlik, güvenlik ve görsel cazibe gibi serbest ölçeklerle incelemiştir. Bayram ve Yaylı (2009) otel web sitelerine dönük yaptıkları içerik analizinde web site değerlendirme ölçütü olarak yedi temel ölçüt üzerinde durmuşlardır. Kullanım kolaylığı, tasarım, yönlendirme, içerik, tüketici hizmetleri, kurumsal bilgi ve güvenlik bu temel ölçütleridir. Tsang, Lai ve Law (2010) çevrimiçi seyahat acentelerinin e-hizmet kalitesini fonksiyonellik, bilgi kalitesi ve içerik, cevap verme süresi, güvenlik, tasarım ve sunum, müşteri ilişkisi olarak altı boyutta incelemiştir. Steinmetz, Levy ve Boo (2013) mobil destinasyon siteleri üzerinde Microsoft Kullanılabilirlik Yönergeleri çerçevesinde içerik ve kullanım kolaylığını incelemiştir.

Kaynama ve Black (2000) seyahat acenteleri web siteleri üzerine yaptığ1 çalışmada acentelerin rezervasyon sistem bilgileri, indirimler, seyahat yerleri, yol tarifleri ve para birimleri gibi benzer özellikleri sunduğunu görülmüştür. Çevrimiçi seyahat acentelerinin rekabet edebilmeleri için öncelikle web sitelerinin yönlendirme ve tasarımının iyi olması gerektiği 
ifade edilmiştir. Bunun için acentelerin çevrimiçi mağaza vitrini olan web sitelerinde dağınıklığın ortadan kaldırması ve tüm sayfalarında tutarlı biryönlendirme sunması gerektiği görülmüştür. Yapılan çalışmada internetin kaliteyi arttırmak için birçok fırsat sunmasına rağmen seyahat acentelerinin etkin ve verimli bir şekilde interneti kullanmadığı görülmüştür.

Roney ve Özturan (2006) Türkiye'de yer alan seyahat acenteleri web sitelerinin ne kadar etkili bir şekilde kullanıldığını içerik analizi yöntemiyle incelenmiştir. Çalışmada web sitelerin içerik, tasarım, satış öncesi ve sonrası bilgilendirme fonksiyonları üzerinde durulmuştur. Sonuç olarak Türkiye' de yer alan seyahat acentelerinin çoğunun interneti elektronik iş olanaklarından tam olarak yararlanmadığı görülmüştür. Bununla birlikte incelenen web sitelerinin hemen hemen hepsinin mevcut ya da potansiyel müşterileri için etkileşim gerektirmeyen kurumsal bilgileri ve temel ürün/hizmet bilgilerini aktarmak için web sitelerini kullandığı görülmüştür.

Park ve diğerleri (2007) çevrimiçi seyahat acenteleri için web sitesi kalitesi ölçümü üzerine yaptığı çalışmasında kullanım kolaylığı, içerik, cevap verme, gizlilik, görsel çekicilik ve güvenlik gibi web sitesi bileşenlerini incelemiştir. Web sitesinin kalitesi seyahat dağıtım işletmelerini rakiplerinden ayıran önemli bir unsur olarak görülmüştür. Bunun için gelecek dönemlerde çevrimiçi acentelerin bahsedilen web sitesi ölçüm bileşenlerindeki eksiklerin giderilmesi tüketiciler tarafından da önemli bulunmuştur. Ayrıca çevrimiçi seyahat acentelerinin teknolojideki hızlı gelişmelere paralel olarak tüketicilerin beklentini ve ihtiyaçlarını web sitelerine yansıtılması gerekliliği de ifade edilmiştir.

Bevanda, Grzinic ve Cervar (2008) kullanıcıların algısını keşfetmek için otomatik bir algoritma kullandığı çalışmasında seyahat acenteleri web siteleri üzerinde tasarım, kullanım kolaylığı, karşılama, yönlendirme, ulaşılabilirlik, kişiselleştirme, etkileşim ve bilgi kalitesi bileşenlerini ölçüm kriterleri olarak kullanmıştır. Web sitelerin kullanıcıya uyan bir şekilde tasarlanması seyahat acentelerinin çevrimiçi çalışmalarının ön şartı olarak görülmüştür. Kullanıcıların ihtiyaçlarını karşılamayacak bir siteyi basitçe terk ettiği vurgulanmış ve farklı kullanıcı tiplerinin memnuniyetini sağlamak için farklı seçeneklerin esnek bir şekilde web sitelerinde olması gerektiği ifade edilmiştir. Bunun yanında bir web sitesinin kullanıcıların tüm ihtiyaçlarını karşılamayacağı teyit edilmiş, bir web sitesinin başarısı 
için ziyaretçi sayısını arttırması ve başka hiçbir sitenin sunmadığı içeriği sunmasının yeterli olacağını savunmuştur. Law, Qi ve Buhalis (2010) ise web sitesi üzerine yaptıkları derinlemesine incelemede web sitesi değerlendirme ve araştırma yöntemlerini sayma yöntemi, kullanıcı karar yöntemi, otomatik yöntemler, sayısal hesaplama yöntemi ve birleştirilmiş yöntemler olarak beş grupta değerlendirmiştir.

Sun, Cárdenas ve Harrill (2016, s.493) müşterilerin bir web sitesini değerlendirirken akılcı ve belirgin bir karar verme süreci kullandıklarını ortaya koymaktadır. Ayrıca web sitesi geliştirilirken göz önüne alınacak faktörlerin sırasının tüketiciler için önemli olduğu ve seyahat acentesi yöneticileri tarafından bu sıralamanın şansa bırakılmaması ifade edilmiştir. Bununla beraber e-iş, e-ticaret, e-turizm ve çevrimiçi seyahat acenteleri kavramlarının el aygıtları ve bulut bilişim sistemi gibi teknolojik gelişmelerle bünyesine yeni müşteri ve tedarikçileri ekleyeceği böylece bu kavramların ilerleyen dönemlerde gelişimini devam ettireceğini öngörmüştür.

\section{Yöntem}

Web sitelerinin içeriklerinin incelenmesi amacıyla araştırmanın ilk aşaması olarak nitel araştırma yöntemlerinden içerik analizine göre daha yüzeysel olan ve genellikle mevcut durumları ortaya çıarmak için kullanılan betimsel analiz kullanılmıştır. Bu kapsamda Tsang ve diğerleri (2010) , Law, Qi ve Buhalis (2010) çalışmaları ile literatür bağlamında incelenen diğer araştırmalar da dikkate alınıp aynı zamanda uzman görüşlerinden de yararlanılarak altı ana ölçüt kategorisi altında 47 değerlendirme bileşeninden oluşan web site değerlendirme ölçeği oluşturulmuş ve bu ölçek doğrultusunda 386 web sitesi betimsel analiz için oluşturulan bu çerçeve doğrultusunda değerlendirilmiştir.

Oluşturulan değerlendirme formunda yer alan görsel tanıtım (kurumsal kimlik), görsel uyumluluk ve bütünlük, bilgi sunumu, müşteri desteği ve hizmetleri, sosyal medya izlenebilirliği ve mobil kullanım ve güvenlik altı ana ölçüt kategorisini oluşturmaktadır. Analiz sonucunda elde edilen bulgular frekans ve yüzde olarak ifade edilmiştir. 
Çalışmanın ikinci aşaması olarak ortaya çıkan altı ana ölçüt ve bu ölçütlerin altında yer alan 47 bileşen üzerinde değişiklik yapılmadan tüketici değerlendirmesini ölçmek için nicel araştırma yöntemleri için veri toplama aracı olan anket tercih edilmiştir. Web sitelerinden betimsel analizi neticesinde elde edilen bileşenler anket için 5'li likert esasına göre yeniden düzenlenmiştir. Kullanılan likert ölçeğinde katılımcıların anket için oluşturulan bileşenlerin önem dereceleri 1- Hiç Önemli Değildir, 2- Önemli Değildir, 3- Kararsızım, 4- Önemlidir, 5- Çok Önemlidir şeklinde değerlendirilmesi istenmiştir. Araştırmanın ikinci kısmında uygulanan anket için internet üzerinden katılımcılara form doldurma imkânı veren çevrimiçi anket uygulaması tercih edilmiştir. Çevrimiçi anket uygulaması uzak yerlerde bulunan katılımcılara erişim, farklı disiplinlerde yer alan birçok katılımcıya ulaşabilme ve otomatik veri toplama kolaylığı gibi avantajlarından dolayı tercih edilmiştir. Bu yöntemi uygulayabilmek için çevrimiçi anket yazılımı ve anket aracı olan "Surveymonkey" (https: //tr.surveymonkey.com/) internet uygulaması kullanılmıştır. İnternet üzerinden yapılan bilimsel çalışmalara yanıt verme oranının yüksek olması ve seyahat etme olasılıklarının yüksek olması varsayılarak veri toplamak için Türkiye'de görev yapmakta olan akademisyenler tercih edilmiştir. Katılım için 3650 adet akademisyene ait e-posta havuzu oluşturulmuş ve betimsel analiz çerçevesine uygun olarak oluşturulan anket, Surveymonkey internet uygulamasıyla havuzda yer alan bütün katılımcılara gönderilmiştir. 3650 akademisyenden \%22 (803) oranında geri dönüş gerçekleşmiştir. Geri dönen anketlerden eksik cevaba rastlanan anketlerin çıkarılmasıyla 742 akademisyenin anketi değerlendirmeye dâhil edilmiştir. Anket sonucunda elde edilen bulgular da frekans ve yüzde analizleri ile değerlendirilmiştir. Son aşamada ise yapılan betimsel analiz ve anket sonucunda ortaya çıkan bulgular tek bir tabloda birleştirilerek karşılaştırılması yapılmiştır.

\section{Araştırmanın Evreni ve Örneklemi}

Çalışmanın genel evrenini Türkiye'de yer alan A sınıfı seyahat acenteleri oluşturmaktadır. TÜRSAB web sitesinden elde edilen bilgiye göre 2018 yılı Ocak ayında Türkiye'de 9144 A sınıfı seyahat acentesi bulunmaktadır. TÜRSAB web sitesinde iletim bilgilerinden web sitesi bulunan seyahat 
acentesi sayısı ise 5790 olarak belirlenmiştir. Örneklem için seyahat acentelerinin bölge dağılımı da dikkate alınarak 386 web sitesinin betimsel analiz için kullanılması uygun görülmüştür. Evrende yer alan web sitelerin özellikleri belirli ölçütler uygulandığında bir birine benzer özellikler gösterebileceğinden ve örneklemi oluşturacak web sitelerinin eşit şansa sahip olması için rastgele seçimle örneklem oluşturma olanağı veren basit tesadüfü örnekleme yöntemi kullanılmıştır.

\section{Araştırmanın Kapsam ve Sınırlılıkları}

Araştırma Türkiye'de yer alan A grubu seyahat acenteleri web sitelerini kapsamaktadır. Betimsel analiz kısmında kullanılan seyahat acenteleri web site adreslerine TÜRSAB web sitesinden ulaşılması, TÜRSAB tarafından tam listenin verilememesi, araştırmanın sadece A grubu seyahat acentelerine yapılmış olması araştırmanın kısıtları arasında yer almaktadır. Türkiye internet alt yapısının birçok gelişmiş ülkeye göre daha yavaş olması web siteleri açılış hızını olumsuz yönde etkileyebilmektedir. Ayrıca araştırma için yapılan değerlendirmelerden sonra web sitelerinde yenileme çalışmaları yapılmış olabilir. Bundan dolayı web sitelerinin dinamik ve hızlı değiştirilebilen yapısı dikkate alınarak belirli dönemlerde yapılacak çalışmalarda değişiklerin izlenmesiyle karşılaştırmalar yapılabilir.

\section{Verilerin Toplanması ve Analizi}

Araştırmanın birinci kısmı için belirlenen seyahat acenteleri web siteleri tek tek ziyaret edilmiş ve oluşturulan web sitesi değerlendirme formuna var (1) veya yok (2) olarak işaretlenmiştir. İncelemesi yapılan web sitesi değerlendirme formunun içerisinden rastgele seçilen web siteleri uzman bir kişi tarafından tekrar değerlendirmeye tabi tutulmuş ve güvenilirliği test edilmiştir. Web sitesi değerlendirme formunda "Görsel Uyumluluk ve Bütünlük" ölçütü altında yer alan web sitesinin hızlı açılması bileşeni GTmetrix ${ }^{1}$ web site analizi programı ile incelenmiştir. Sosyal Medya İzlenebilirliği ve Mobil Kullanım ölçütü altında yer alan web sitesinin mobil

\footnotetext{
${ }^{1}$ GTmetrix; web sitelerin url adreslerine göre açılış hızı ve performans bileşenlerini ölçen bir web uygulamasıdır.
} 
telefonlarla uyumu bileşeni ölçümünde ise Google Mobil Uyumluluk Testi kullanılmıştır.

Araştırmanın ikinci kısmında yer alan çevrimiçi anket, Surveymonkey internet uygulaması ile yapılmıştır. Surveymonkey web sitesi üzerinden üyelik sistemi açılmış ve oluşturulan web sitesi değerlendirme formu anket olarak web sitesinin anket oluşturma araçlarından faydalanılarak oluşturulmuştur. Oluşturulan anket formu 20 katılımcıya ön test olarak eposta adreslerine yollanmış ve anket geri dönüşleri incelenmiştir. Ön test için yollanan çevrimiçi anketler asıl veriler dişında tutulmuştur. İnternet üzerinden oluşturulan anket formu e-posta havuzunda yer alan tüm kat1lımcılara yollanmış ve veriler Surveymonkey uygulaması tarafından anlık olarak kayıt altına alınmıştır. Web sitesi değerlendirme formundan ve anketten elde edilen tüm veriler SPSS programına aktarılmış ve verilerin analizi için betimleyici (descriptive) analiz tekniklerinden frekans ve yüzde analizi kullanılmıştır.

\section{Araştırmanın Güvenilirlik ve Geçerliliği}

Araştırmada yer alan web sitesi değerlendirme ölçeğinin bütün bileşenlerinin güvenilirliğini test etmek için hesaplanan Alfa katsayı değeri 0,814'dür. Araştırmanın ikinci kısmını oluşturan anket formu ölçeğinin güvenilirliğini test etmek için hesaplanan Alfa katsayı değeri ise $0,908^{\prime}$ dir. Araştırmada kullanılan web site değerlendirme bileşenleri iki bilgisayar mühendisi, bir seyahat acentesi genel müdürü ve bir akademisyen tarafından uzaman görüşü alınarak değerlendirilmiş ve web sitesinde olması gereken bileşenler yeterli olarak görülmüştür.

\section{Bulgular}

Araştırma kapsamında 742 katılımcının anketi değerlendirmeye alınmış olup, anketi cevaplayanlara ilişkin demografik (cinsiyet, yaş, medeni durum ve eğitim durumu) ve diğer bireysel özelliklerine (yaşanılan bölge,

\footnotetext{
2 Google Mobil Uyumluluk Testi; web sitelerin url adreslerine göre mobil cihazlarla uyumlu olup olmadığını test eden bir web uygulamasıdır.
} 
internet kullanımı vb.) ait tanımlayıcı bilgilere Tablo 2 ve Tablo 3'de yer verilmiştir.

Tablo 2 incelendiğinde, araştırmaya katılanların \% 52'si ( $\mathrm{f}=386$ ) erkek, $\%$ 48'si (f=356) kadındır. Katılımcıların yaşlarına göre dağılımı incelendiğinde, \%0,9'unun ( $\mathrm{f}=7$ ) 25 yaş ve altı, \%52'sinin ( $\mathrm{f}=386$ ) 26-35, \%32,1'inin ( $\mathrm{f}=238$ ) $36-45$, \%11,3'ün ( $\mathrm{f}=84$ ) 46-55 yaş aralıklarında ve \%3,6'sının ise $(\mathrm{f}=27) 56$ yaş ve üzerinde olduğu gözükmektedir. Araştırmaya katılanların eğitim düzeyleri incelendiğinde \% 3 ' $\mathbf{u}$ lisans (f=22), \%30,3’ü (f=225) yüksek lisans ve $\% 66,7^{\prime} \operatorname{sinin}$ ise ( $\left.\mathrm{f}=495\right)$ doktora düzeyinde oldukları gözükmektedir. Katılımcıların yaşadıkları bölgelere göre dağılımı incelendiğinde \%22,8'i (f=169) Marmara Bölgesi'nden, \%18,2'si (f=135) İç Anadolu Bölgesi'nden, \%14'ü ( $\mathrm{f}=104)$ Ege Bölgesi'nden, \%12'si ( $\mathrm{f}=89)$ Akdeniz Bölgesi'nden, \%11,3'ü (f=84) Doğu Anadolu Bölgesi'nden, \%15,6's1 (f=116) Karadeniz Bölgesi'nden ve \%6,1'i (f=45) Güney Doğu Anadolu Bölgesi'nden oldukları gözükmektedir.

Tablo 2. Katılımcıların Demografik Özelliklerine İlişkin Bulgular

\begin{tabular}{llll}
\hline Değişkenler & Gruplar & $f$ & \% \\
\hline \multirow{2}{*}{ Cinsiyet } & Kadın & 356 & 48,0 \\
& Erkek & 386 & 52,0 \\
\hline \multirow{4}{*}{ Yaş } & 25 yaş ve altı & 7 & 0,9 \\
& 26-35 yaş & 386 & 52,0 \\
& 36-45 yaş & 238 & 32,1 \\
& $46-55$ yaş & 84 & 11,3 \\
& 56 yaş ve üzeri & 27 & 3,6 \\
\hline \multirow{3}{*}{ ğitim Düzeyi } & Lisans & 22 & 3,0 \\
& Yüksek Lisans & 225 & 30,3 \\
& Doktora & 495 & 66,7 \\
\hline & Marmara Bölgesi & 169 & 22,8 \\
& İç Anadolu Bölgesi & 135 & 18,2 \\
& Ege Bölgesi & 104 & 14,0 \\
Yaşanılan Bölge & Akdeniz Bölgesi & 89 & 12,0 \\
& Doğu Anadolu Bölgesi & 84 & 11,3 \\
& Karadeniz Bölgesi & 116 & 15,6 \\
& Güney Doğu Anadolu Bölgesi & 45 & 6,1 \\
\hline
\end{tabular}


Tablo 3'e ait tanımlayıcı bilgilerden internet kullanım süresine göre dağllım incelendiğinde katılımcıların en az kullanım süresine sahip kesiminin 1-3 yıl aralığında olup (\%0,8;f=6), 4-6 yıl aralığında \%3,1'i (f=23) ve 7-

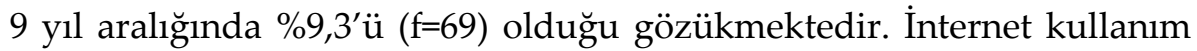
süresinin en yüksek olduğu aralık ise 9 yıldan daha fazla kullanım süresine sahip (\%86,8; $\mathrm{f}=644)$ katılımcılardır. Araştırmaya katılanların tanımlayıcı bilgilerinden internet kullanım sıklığı incelendiğinde katılımcıların $\% 17,9^{\prime} \mathrm{u}$ ( $\mathrm{f}=133$ ) günde 1-2 saat, $\% 33,2(\mathrm{f}=246)$ günde $3-4$ saat, $\% 47,2^{\prime}$ si $(\mathrm{f}=350)$ günde 5 saatten fazla, \%0,3'ü (f=2) haftada birkaç gün, \%1,5'i ise $(\mathrm{f}=11)$ haftada 3-4 gün olarak internette vakit geçirdikleri gözükmektedir.

Tablo 3. Katılımcıların Tanımlayıcı Özelliklerine İlişkin Bulgular

\begin{tabular}{llll}
\hline Değişkenler & Gruplar & $f$ & \% \\
\hline \multirow{2}{*}{ İnternet Kullanım Süresi } & $1-3$ yıl & 6 & 0,8 \\
& $4-6$ yıl & 23 & 3,1 \\
& $7-9$ yıl & 69 & 9,3 \\
& 9 yıldan fazla & 644 & 86,8 \\
\hline \multirow{2}{*}{ Internet Kullanım Sıklığ1 } & Günde 1-2 saat & 133 & 17,9 \\
& Günde 3-4 saat & 246 & 33,2 \\
& Günde 5 saatten fazla & 350 & 47,2 \\
& Haftada birkaç gün & 2 & 0,3 \\
& Haftada 3-4 gün & 11 & 1,5 \\
\hline Mobil Cihazlardan İnternete & Evet & 704 & 94,9 \\
Bağlanma Durumu & Hayır & 38 & 5,1 \\
\hline
\end{tabular}

Araştırmaya katılanların neredeyse tamamına yakını (\%94,6;f=704) mobil cihazlar üzerinden internete erişim sağlarken, katılımcıların \%5, $1^{\prime} i$ $(\mathrm{f}=38)$ mobil cihazlardan internete bağlanmamayı tercih etmektedirler.

Betimsel analiz sonucunda ortaya çıkmış görsel tanıtım bileşenlerine ilişkin mevcut durum ile tüketicilere yapılan anket değerlendirmelerinin karşılaştırılması ve bu karşılaştırma sonucunda ortaya çıkan sıralama Tablo 4'de gösterilmiştir. Tablo 4'e göre seyahat acenteleri web sitelerinin $\% 97,7$ 'sinde görsel tanıtım bileşenleri içinde işletmelerce en çok yer verilen özelliğin logo olduğu, bu özelliğin web sitelerinde olması tüketiciler tarafından da çok önemli $(\bar{X}=4,21)$ olarak değerlendirilmekte ve tüketici öncelikleri açısından sıralandığında ikinci sırada yer almaktadır. Tüketiciler tarafından görsel tanıtım bileşenleri içinde önem derecesine göre ilk 
sırada yer alan hakkımızda sayfasının web sitelerinin içerik analizi sonuçlarını yansitan mevcut durumda da \%76,4'ünde bulunduğu görülmektedir. Görsel tanıtım bileşenlerinden vizyon ve misyona ilişkin karşılaştırmaya bakıldığında hem vizyonun ( $\bar{X}=3,98)$ hem de misyonun $(\bar{X}=3,95)$ web sitelerinde olması tüketiciler tarafından önemli olarak değerlendirildiği görülmektedir. Bununla birlikte vizyon ifadesinin web sitelerinde yer almasının misyon ifadesine göre tüketicilerce biraz daha önemli olduğu görülmektedir.

Tablo 4. Görsel Tanıtım Bileşenlerine İlişkin Mevcut Durum ile Tüketici Değerlendimelerinin Karşılaştırılması

\begin{tabular}{|c|c|c|c|c|c|c|c|c|c|c|c|c|c|}
\hline \multirow{3}{*}{$\begin{array}{l}\text { Görsel Ta- } \\
\text { nıtım } \\
\text { (Kurumsal } \\
\text { Kimlik) } \\
\text { Bileşenleri }\end{array}$} & \multirow{2}{*}{\multicolumn{2}{|c|}{$\begin{array}{l}\text { Mevcut } \\
\text { Durum } \\
\text { “Var" } \\
(n=386)\end{array}$}} & \multirow{2}{*}{$\begin{array}{c}\mathrm{S} \\
\mathrm{I} \\
\mathrm{R} \\
\mathrm{A} \\
\mathrm{L} \\
\mathrm{A} \\
\mathrm{M} \\
\mathrm{A} \\
\end{array}$} & \multicolumn{8}{|c|}{$\begin{array}{l}\text { Tüketicilerin Değerlendirmesi } \\
\qquad(n=742)\end{array}$} & \multirow{3}{*}{$\bar{X}$} & \multirow{3}{*}{ s.s. } \\
\hline & & & & \multicolumn{3}{|c|}{ 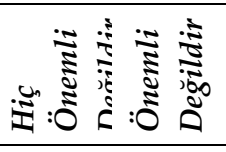 } & $\begin{array}{r}\frac{1}{3} \\
\frac{2}{2} \\
1\end{array}$ & \multirow[t]{2}{*}{$\begin{array}{c}\frac{1}{N} \\
\text { के } \\
0\end{array}$} & \multicolumn{2}{|c|}{ 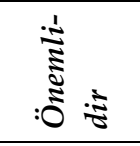 } & $\overbrace{}^{\frac{0}{2}}: \frac{0}{\frac{1}{2}}=$ & & \\
\hline & $\mathrm{f}$ & $\%$ & $\leftarrow \rightarrow$ & $\mathrm{f}$ & $\%$ & $\mathrm{f} \quad \%$ & $\mathrm{f}$ & & $\mathrm{f}$ & $\%$ & $\%$ & & \\
\hline Logo & 377 & 97,7 & 12 & 6 & 0,8 & $33 \quad 4,4$ & 51 & 6,9 & 354 & 47,7 & $298 \quad 40,2$ & 4,21 & 0,82 \\
\hline Vizyon & 78 & 20,2 & $\begin{array}{ll}43 \\
\end{array}$ & 17 & 2,3 & $69 \quad 9,3$ & 71 & 9,6 & 337 & 45,4 & $248 \quad 33,4$ & 3,98 & 1,00 \\
\hline Misy & 82 & 21,2 & 34 & 16 & 2,2 & $69 \quad 9,3$ & 81 & 10,9 & 339 & 45,7 & 23731,9 & 3,95 & 0,99 \\
\hline Slogan & 72 & 18,7 & $\begin{array}{ll}55 \\
\end{array}$ & 14 & 1,9 & $\begin{array}{ll}68 & 9,2 \\
\end{array}$ & 101 & 13,6 & 338 & 45,6 & $221 \quad 29,8$ & 3,92 & 0,98 \\
\hline $\begin{array}{l}\text { Hakk1- } \\
\text { mıda } \\
\text { Sayfası }\end{array}$ & 295 & 76,4 & 21 & 3 & 0,4 & 273,6 & 50 & 6,7 & 297 & 40 & 36549,2 & 4,33 & 0,79 \\
\hline
\end{tabular}

İşletmenin kendisine ait sloganının web sitesinde olmasına ilişkin karşılaştırmaya bakıldığında ise hem seyahat acenteleri web sitelerinin mevcut durumunda hem de katılımcıların önem düzeyi sıralamasında bu bileşenin en sonda yer aldığı görülmektedir.

Tablo 4 genel olarak incelendiğinde seyahat acenteleri web sitelerinde görsel kimlik öğesi altında yer alan işletmeye ait logo ve hakkımızda sayfasının olması bileşenlerine önem verdiği görülürken, tüketicilerin de bu iki bileşenin web sitelerinde yer almasını önemsedikleri görülmektedir. Bunun yanında yine tüketiciler tarafından önemsenen vizyon, misyon ve işletmenin sloganı bileşenlerine seyahat acenteleri web sitelerinde daha az yer verdikleri görülmektedir. Seyahat acentelerinin amaç, görev ve gele- 
cekteki hedeflerine yer vermemesi ve kurumsal imajını yansıtan bir söyleminin olmaması tüketiciler tarafından kurumsal güven eksikliği olarak görülebilmektedir. Görsel uyumluluk ve bütünlük bileşenlerine ilişkin mevcut durum ile tüketici değerlerinin kıyaslaması Tablo 5'de gösterilmiştir.

Tablo 5: Görsel Uyumluluk ve Bütünlük Bileşenlerine İlişkin Mevcut Durum ile Tüketici Değerlendirmelerinin Karşılaştırılması

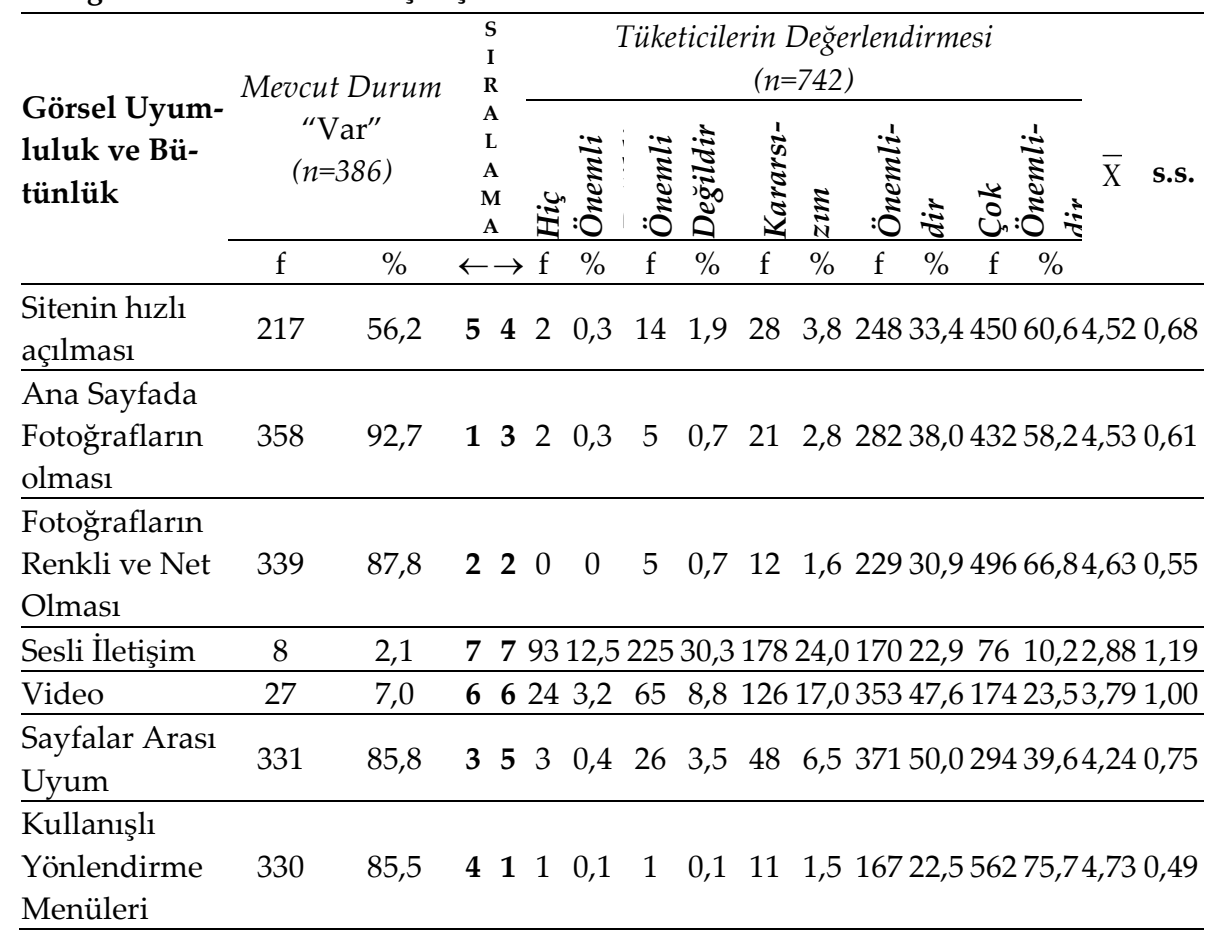

Tablo 5 incelendiğinde seyahat acenteleri web sitelerinde görsel uyumluluk ve bütünlük başlığı altında en çok yer alan bileşen olarak ana sayfada fotoğrafların ( $\mathrm{f}=358 ; \% 92,7$ ) olduğu görülmektedir. Bu özelliğin web sitelerinde olması tüketiciler açısından da çok önemli ( $\bar{X}=4,53)$ olarak değerlendirilmekte ve önem deresi açısından sıralandığında üçüncü sırada yer almaktadır. Tüketiciler tarafından önem derecesi incelendiğinde ilk s1rada yer alan bileşenin kullanışlı yönlendirme menüleri $(\bar{X}=4,73)$ olduğu 
görülmektedir. Mevcut durumda bu bileşenin seyahat acentelerin web sitelerinin \%85,5'inde bulunduğu görülmektedir.

Tablo 5 genel olarak incelendiğinde seyahat acenteleri web sitelerinde yer alan görsel uyumluluk ve bütünlük bileşenlerinin mevcut durumları ile tüketicilerin önem düzeyi sıralaması yakın olarak görülmektedir. Web sitelerin görsel sunumu tüketiciler tarafından önemsenmekte olup; mevcut durumda yer alan değerler de seyahat acentelerinin bu ölçeğe önem verdikleri şeklinde yorumlanabilir. Bununla birlikte tüketiciler tarafından daha çok önemsenen videolara yer verilmesi seyahat acenteleri tarafından biraz daha dikkate alınabilir.

Acentelerin özellikle ürün sunumlarında ürünü tanıtıcı videolara yer vermesi tüketiciler tarafından ürünün daha anlaşılır olmasını sağlayabilir. Hac ve Umre organizasyonu yapan seyahat acentelerinde sesli iletişim bileşeni tüketicilerin manevi değerlerini arttıracağ 1 şeklinde düşünülebilirken diğer acente faaliyeti gösteren seyahat acenteleri web sitelerinde bu bileşenin kullanılma durumu hem mevcut durum hem de tüketici önem düzeyi sıralamasında en az önem verilen bileşen olarak görülmektedir. Tablo 6'da ise betimsel analiz sonucunda ortaya çıkmış bilgi sunumu bileşenlerine ilişkin mevcut durum ile tüketicilere yapılan anket değerlerinin karşılaştırılması gösterilmiştir.

Tablo 6'ya göre seyahat acentelerinin mevcut durumda bilgi sunumu ölçeği altında web sitelerinde en çok yer verdikleri bileşen olarak sunulan ürünlerin özelliklerinin belirtilmesi ( $\mathrm{f}=312 ; \% 80,8)$ görülmektedir. Bu bileşenin web sitelerinde ürün sunumunda olması tüketiciler tarafından da çok önemli ( $\bar{X}=4,75)$ olarak değerlendirilmekte ve tüketiciler tarafından önem düzeyi sıralamasına göre üçüncü sırada yer almaktadır. Tüketicilerin önem düzeyi sıralaması incelendiğinde mevcut durumdan farklı olarak sunulan ürünün fiyatının belli olması $(\bar{X}=4,87)$ tüketicileri tarafından en çok önemsenen bileşen olarak görülmektedir. Bu bileşenin mevcut durumuna bakıldığında web sitelerin \%62,4'ünde sunulan ürünün fiyatının belli olduğu görülmektedir.

Mevcut durum sıralamasında ikinci bileşen olarak görülen sunulan ürünün çoklu ortam araçlarıyla desteklenmesi bileşeni seyahat acenteleri web sitelerinin \%73,8'inde kullanılırken; tüketici önem düzeyi sıralamasinda sunulan ürünün kampanya ve indirimlerle desteklenmesi $(\bar{X}=4,76)$ 
ikinci bileşen olarak görülmektedir. Sunulan ürünün kampanya ve indirim bilgilerinin mevcut durumda ise web sitelerinin \%45,6'sında olduğu görülmektedir.

Tablo 6: Bilgi Sunumu Bileşenlerine İlişkin Mevcut Durum ile Tüketici Değerlerinin Karşılaştırılması

\begin{tabular}{|c|c|c|c|c|c|c|c|c|c|c|c|c|c|c|}
\hline \multirow{3}{*}{$\begin{array}{l}\text { Bilgi } \\
\text { Sunumu }\end{array}$} & \multirow{2}{*}{\multicolumn{2}{|c|}{$\begin{array}{l}\text { Mevcut } \\
\text { Durum } \\
\text { "Var" } \\
(n=386)\end{array}$}} & \multirow{2}{*}{$\begin{array}{c}\mathrm{S} \\
\mathrm{I} \\
\mathrm{R} \\
\mathrm{A} \\
\mathrm{L} \\
\mathrm{A} \\
\mathrm{M} \\
\mathrm{A}\end{array}$} & \multicolumn{9}{|c|}{$\begin{array}{l}\text { Tüketicilerin Değerlendirmesi } \\
(n=742)\end{array}$} & \multirow{3}{*}{$\bar{X}$} & \multirow{3}{*}{ s.s. } \\
\hline & & & & : & & 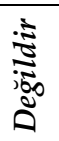 & & $\underset{\substack{N \\
\text { a }}}{\mathbb{N}}$ & : & & $\ddot{u}:$ & ڤે & & \\
\hline & $f$ & $\%$ & $\leftarrow \rightarrow$ & $f \quad \%$ & $\mathrm{f}$ & $\%$ & $f$ & $\%$ & $f$ & $\%$ & $\mathrm{f}$ & $\%$ & & \\
\hline $\begin{array}{l}\text { Site içi } \\
\text { arama mo- } \\
\text { toru }\end{array}$ & 133 & 34,5 & 66 & $\begin{array}{ll}4 & 0,5\end{array}$ & 18 & 2,4 & 24 & 3,2 & 273 & 36,8 & 423 & 57,0 & 4,47 & 0,72 \\
\hline $\begin{array}{l}\text { Ürün özel- } \\
\text { liklerinin } \\
\text { belirtilmesi }\end{array}$ & 312 & 80,8 & 130 & $\begin{array}{ll}0 & 0\end{array}$ & 0 & 0 & 3 & 0,4 & 179 & 24,1 & 560 & 75,5 & 4,75 & 0,44 \\
\hline $\begin{array}{l}\text { Ürünün fi- } \\
\text { yatının belli } \\
\text { olması }\end{array}$ & 241 & 62,4 & 31 & $\begin{array}{ll}0 & 0\end{array}$ & 1 & 0,1 & 4 & 0,5 & 82 & 11,1 & 655 & 88,3 & 4,87 & 0,35 \\
\hline $\begin{array}{l}\text { Ürünün } \\
\text { çoklu ortam } \\
\text { kullanımı }\end{array}$ & 285 & 73,8 & 25 & $\begin{array}{lll}1 & 0,1\end{array}$ & 3 & 0,4 & 37 & 5,0 & 254 & 34,2 & 447 & 60,2 & 4,54 & 0,62 \\
\hline $\begin{array}{l}\text { Ürünlerin } \\
\text { kampanya } \\
\text { ve indirim } \\
\text { bilgileri }\end{array}$ & 176 & 45,6 & 42 & $\begin{array}{ll}0 & 0\end{array}$ & 2 & 0,3 & 3 & 0,4 & 164 & 22,1 & 573 & 77,2 & 4,76 & 0,45 \\
\hline $\begin{array}{l}\text { Ürüne ait } \\
\text { tamamlayıcı } \\
\text { linkler }\end{array}$ & 135 & 35,0 & 573 & $\begin{array}{ll}3 & 0,4\end{array}$ & 22 & 3,0 & 52 & 7,0 & 319 & 43,0 & 346 & 46,6 & 4,32 & 0,76 \\
\hline $\begin{array}{l}\text { Kullanıc1 } \\
\text { tecrübele- } \\
\text { rine ait yo- } \\
\text { rumlar } \\
\end{array}$ & 31 & 8,0 & 742 & 20,3 & 6 & 0,8 & 18 & 2,4 & 189 & 25,5 & 527 & 71,0 & 4,66 & 0,59 \\
\hline
\end{tabular}

Tüketici önem düzeyi sıralamasında ve mevcut durum karşılaştırmasında site içi arama motoru ( $\mathrm{f}=133$; $\% 34,5)$ bileşeni aynı sıralamada görülmektedir ve tüketiciler tarafından çok önemli $(\bar{X}=4,47)$ bir bileşen olarak 
görülmektedir. Bunun yanında mevcut durum sıralamasında en sonda görülen kullanıcı tecrübelerine ait yorumların seyahat acenteleri web sitelerin sadece $\% 8$ inde yer verilmesine karşıllk tüketici önem düzeyi sıralamasında dördüncü sırada ve çok önemli bir bileşen $(\bar{X}=4,66)$ olarak görülmektedir. Tüketicilerin önem düzeyi sıralamasında ise son sırada yer alan bileşenin ürüne ait tamamlayıcı linkler $(\bar{X}=4,32)$ olduğu buna karşılik bu bileşenin mevcut durumda seyahat acenteleri web sitelerinin \%35'inde kullanıldığı görülmektedir.

Tablo 6 genel olarak incelendiğinde bilgi sunumu ölçeği altında yer alan bileşenler tüketiciler tarafından çok önemsenmektedir. Buna karşılık mevcut durumda yer alan bileşenlerden ürüne ait tamamlayıcı linkler, site içi arama motoru ve kullanıcı tecrübelerine ait yorumların web sitelerinde daha az kullanıldığı görülmektedir. Tüketicilerin önem düzeyi sıralamasına bakıldığında tüketiciler daha çok satın alacağı ürüne ait temel bileşenlere (fiyat, kampanya, ürün özellikleri vb.) önem verirken seyahat acenteleri web sitelerin mevcut durum sıralamasının da benzer olduğu görülmektedir.

Tablo 7 'de ise müşteri desteği ve hizmetleri bileşenlerine ilişkin mevcut durum ile tüketici değerlerinin karşılaştırılması gösterilmiştir. Buna göre tüketici önem düzeyi sıralamasına göre ilk sırada yer alan bileşenin seyahat acenteleri web sitelerinin ana sayfasında çağrı hizmetleri numarasinın olması ( $\bar{X}=4,65)$ yer almaktadır.

Mevcut durum incelendiğinde çağrı hizmetleri numarasının olması web sitelerinin \%68,7'sinde olduğu görülmektedir. Müşteri desteği ve hizmetleri ölçeğinin mevcut durumda web sitelerinde en çok yer alan bileşeni olarak kurumun ayrı bir iletişim sayfasının olması ( $\mathrm{f}=362 ; \% 93,8)$ yer almaktadır. Tüketiciler açısından karşılaştırıldığında önem düzeyi sıralamasında iletişim sayfanın olması sıralamada ikinci ve çok önemli $(\bar{X}$ $=4,51$ ) olduğu görülmektedir. Bununla birlikte seyahat acenteleri web sitelerinin $\% 71,8^{\prime}$ inde var olan müşteri geri bildirim formu ( $\left.\mathrm{f}=277\right)$ hem mevcut durumda hem de tüketicilerin değerlendirmesinde $(\bar{X}=4,51)$ siralama olarak karşılaştırıldığında ikinci olarak görülmektedir. 
Tablo 7: Müşsteri Desteği ve Hizmetleri Bileşenlerine İlişkin Mevcut Durum ile Tüketici Değerlerinin Karşılaştırılması

\begin{tabular}{|c|c|c|c|c|c|c|c|c|c|c|c|c|c|c|c|c|}
\hline \multirow{3}{*}{$\begin{array}{c}\text { Müşteri } \\
\text { Desteği ve } \\
\text { Hizmetleri }\end{array}$} & \multirow{2}{*}{\multicolumn{3}{|c|}{$\begin{array}{c}\text { Mevcut Du- } \\
\text { rum } \\
\text { "Var" } \\
(n=386)\end{array}$}} & \multirow{2}{*}{$\begin{array}{c}\mathrm{S} \\
\mathrm{I} \\
\mathrm{R} \\
\mathrm{A} \\
\mathrm{L} \\
\mathrm{A} \\
\mathrm{M} \\
\mathrm{A} \\
\end{array}$} & \multicolumn{11}{|c|}{$\begin{array}{l}\text { Tüketicilerin Değerlendirmesi } \\
\qquad(n=742)\end{array}$} & \multirow{3}{*}{ s.s. } \\
\hline & & & & & & 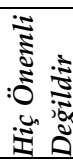 & & 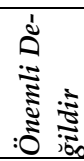 & & 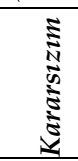 & & 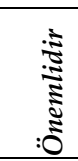 & & 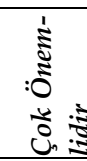 & & \\
\hline & $\mathrm{f}$ & & $\%$ & $\leftarrow$ & $\rightarrow \mathrm{f}$ & f $\%$ & $\%$ & f $\%$ & & f $\quad$ o & $\%$ & f $\quad$ o & $\%$ & $\mathrm{f} \quad \mathrm{o}$ & $\%$ & \\
\hline $\begin{array}{l}\text { Ana sayfada } \\
\text { çağnı hizmet- } \\
\text { leri numarası }\end{array}$ & 265 & 68,7 & 73 & 1 & 1 & 0,1 & 2 & 0,3 & 10 & 1,3 & 224 & 30,2 & 505 & 588,1 & 4,65 & $5 \quad 0,53$ \\
\hline $\begin{array}{l}\text { Müşteri geri } \\
\text { bildirim } \\
\text { formu }\end{array}$ & 277 & 71,8 & & 2 & 1 & 0,1 & 13 & 1,8 & 19 & 2,6 & 276 & 37,2 & 433 & 358,4 & 4,51 & 10,65 \\
\hline SSS menüsü & 8 & 2,1 & 19 & 3 & 2 & 0,3 & 33 & 4,4 & 49 & 6,6 & 338 & 45,6 & 320 & 43,6 & 4,26 & $\begin{array}{ll}6 & 0,79\end{array}$ \\
\hline $\begin{array}{l}\text { Çevri- } \\
\text { miçi/Anlık } \\
\text { mesajlaşma } \\
\end{array}$ & 20 & 5,2 & 27 & 3 & 3 & 0,4 & 25 & 3,4 & 67 & 9,0 & 326 & 43,9 & 321 & 143,3 & 4,26 & $6 \quad 0,79$ \\
\hline $\begin{array}{l}\text { Yardım me- } \\
\text { nüsü }\end{array}$ & 8 & 2,1 & 19 & 4 & 6 & 0,8 & 15 & 2,0 & 75 & 10,1 & 331 & 44,6 & 315 & $5 \quad 42,5$ & 4,25 & $5 \quad 0,78$ \\
\hline $\begin{array}{l}\text { İletişim say- } \\
\text { fası }\end{array}$ & 362 & 93,8 & 81 & 2 & 1 & 0,1 & 12 & 1,6 & 31 & 4,2 & 257 & 34,6 & 441 & 159,4 & $=4,51$ & 10,66 \\
\hline $\begin{array}{l}\text { Takvim Bil- } \\
\text { gisi }\end{array}$ & 76 & 19,7 & 75 & 7 & 29 & 3,9 & 94 & 12,7 & 105 & 14,2 & 285 & 38,4 & 229 & 930,9 & 3,79 & $9 \quad 1,12$ \\
\hline $\begin{array}{l}\text { Döviz Çevi- } \\
\text { rici }\end{array}$ & 3 & 0,8 & 810 & 9 & 43 & 5,8 & 157 & 21,2 & 158 & 21,3 & 264 & 35,6 & 120 & $\begin{array}{ll}0 & 16,2\end{array}$ & . 3,35 & $5 \quad 1,15$ \\
\hline $\begin{array}{l}\text { Güncel Döviz } \\
\text { Kuru }\end{array}$ & 10 & 2,6 & 68 & 8 & 39 & 5,3 & 136 & 18,3 & 137 & 18,5 & 296 & 39,9 & 134 & $4 \quad 18,1$ & 3,47 & $.7 \quad 1,13$ \\
\hline $\begin{array}{l}\text { Ziyaretçi def- } \\
\text { teri veya yo- } \\
\text { rum formu } \\
\end{array}$ & 47 & 12,2 & 26 & 6 & 8 & 1,1 & 42 & 5,7 & 94 & 12,7 & 323 & 43,5 & 275 & $5 \quad 37,1$ & 4,09 & $9 \quad 0,90$ \\
\hline $\begin{array}{l}\text { Çoklu dil se- } \\
\text { çeneği }\end{array}$ & 128 & 33,2 & 24 & 5 & 6 & 0,8 & 38 & 5,1 & 61 & 8,2 & 325 & 43,8 & 312 & 242,0 & 4,21 & $1 \quad 0,85$ \\
\hline
\end{tabular}

Müşteri desteği ve hizmetleri başlığı altında seyahat acenteleri web sitelerinin mevcut durumunda en az yer verilen bileşenin döviz çevirici $(\mathrm{f}=3 ; \% 0,8)$ olduğu görülmektedir. Bu bileşenin web sitelerinde olması tüketiciler tarafından da önem düzeyi diğer bileşenlerden daha düşük olduğu ve tüketici öncelikleri açısından sıralandığında en sonra sırada ( $\bar{X}$ $=3,35$ ) yer aldığı görülmektedir. 
Tablo 7 genel olarak incelendiğinde seyahat acentelerinin mevcut durumda sıkça yer verdikleri bileşenler tüketiciler açısından da önemli olarak görülmektedir. Fakat mevcut durum siralamasında son siralarda yer alan çevrimiçi mesajlaşma, SSS menüsü ve yardım menüsü bileşenlerinin web sitelerin çok azında yer verildiği görülürken bu bileşenlerin tüketiciler tarafından daha çok önemsendiği görülmektedir. Özellikle günümüzde web sitelerinin daha iyi ve hızlı bir hizmet için tüketicilere sunduğu anlık mesajlaşma özelliği seyahat acenteleri web sitelerin $\% 5,2$ 'sinde yer almaktadır. Tüketiciler açısından çok önemli ( $\bar{X}=4,26)$ olarak görülen bu özelliğin web sitelerinde daha sık kullanılması kurumun müşterisine anında desteği ile hem müşteriyi kuruma bağlama açısından hem de rekabet avantajı yaratması açısından bir fark yaratabileceği şeklinde yorumlanabilir.

Betimsel analiz sonucunda ortaya çıkmış sosyal medya izlenebilirliği ve mobil kullanım bileşenlerine ilişkin mevcut durum ile tüketicilere yapılan anket değerlerinin karşılaştırılması Tablo 8'de gösterilmiştir. Buna göre seyahat acenteleri web sitelerinin sosyal medya izlenebilirliği ve mobil kullanımı ölçeğinde mevcut durum sıralamasında en üstte yer verilen bileşen olarak en az bir tane sosyal medya erişim butonu ( $\mathrm{f}=251$; \%65) olarak görülmektedir. Tüketicilerin önem düzeyi sıralamasına göre de bu bileşen önemli olarak ( $\bar{X}=3,57)$ değerlendirilmektedir.

Tüketicilerin değerlendirilmesi incelendiğinde web sitelerin mobil cihazlarla uyumlu olması bileşeni tüketici değerlendirmesinde ilk sırada görülürken, mevcut durumda seyahat acentelerinin \%54,4'ünün mobil cihazlarla uyumlu olduğu görülmektedir.

Sosyal medya araçları incelendiğinde seyahat acentelerin web sitelerin \%62,4'ünden facebook sayfalarına erişim olduğu görülmektedir. Aynı bileşen tüketiciler tarafından da önemli olarak ( $\bar{X}=3,27)$ olarak görülmektedir. Tüketici değerlendirmesinde çok önemli olarak görülen bir diğer bileşen ise kurumun mobil uygulamasının $(\bar{X}=4,19)$ olmasıdır. Bu bileşenin mevcut durum ile karşılaştırılması incelendiğinde tüketici sıralamasında ikinci sırada yer alırken mevcut durumda seyahat acenteleri web sitelerinin yalnızca \%3,1'inde (f=12) kullanıldığı ve son sırada yer aldığı görülmektedir. 
Tablo 8. Sosyal Medya İzlenebilirliği ve Mobil Kullanım Bileşenlerine İlişkin Mevcut Durum İle Tüketici Değerlerinin Karşılaştırılması

\begin{tabular}{|c|c|c|c|c|c|c|c|c|c|c|c|c|c|c|c|c|}
\hline \multirow{3}{*}{$\begin{array}{c}\text { Sosyal Medya } \\
\text { İzlenebilirliği } \\
\text { Ve Mobil Kul- } \\
\text { lanım }\end{array}$} & \multirow{2}{*}{\multicolumn{2}{|c|}{$\begin{array}{l}\text { Mevcut } \\
\text { Durum } \\
\text { "Var" } \\
(n=386)\end{array}$}} & \multirow{2}{*}{\multicolumn{2}{|c|}{$\begin{array}{l}\mathrm{S} \\
\mathrm{I} \\
\mathrm{R} \\
\mathrm{A} \\
\mathrm{L} \\
\mathrm{A} \\
\mathrm{M} \\
\mathrm{A} \\
\end{array}$}} & \multicolumn{10}{|c|}{$\begin{array}{l}\text { Tüketicilerin Değerlendirmesi } \\
(n=742)\end{array}$} & \multirow{3}{*}{$\bar{X}$} & \multirow{3}{*}{ s.s. } \\
\hline & & & & & & $\sum_{\substack{5 \\
\vdots \\
0}}^{\infty}$ & 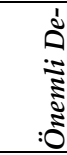 & $\sum_{i=0}^{\frac{1}{5}}$ & & 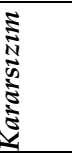 & & 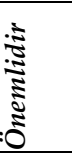 & 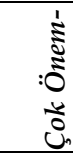 & 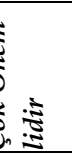 & & \\
\hline & $\mathrm{f}$ & $\%$ & $\leftarrow$ & $\rightarrow$ & $\Rightarrow \mathrm{f}$ & $\%$ & $\mathrm{f}$ & $\%$ & $\mathrm{f}$ & $\%$ & $\mathrm{f}$ & $\%$ & $\mathrm{f}$ & $\%$ & & \\
\hline $\begin{array}{l}\text { Sosyal medya } \\
\text { erişim butonu }\end{array}$ & 251 & 65,0 & 01 & 3 & 22 & 3,0 & 125 & 16,8 & 146 & 19,7 & 301 & 40,6 & 148 & 19,9 & 3,57 & 1,07 \\
\hline $\begin{array}{l}\text { Facebook eri- } \\
\text { șimi }\end{array}$ & 241 & 62,4 & 42 & 4 & 40 & 5,4 & 159 & 21,4 & 195 & 26,3 & 252 & 34,0 & 96 & 12,9 & 3,27 & 1,10 \\
\hline $\begin{array}{l}\text { Youtube eri- } \\
\text { şimi }\end{array}$ & 69 & 17,9 & 97 & 6 & 43 & 5,8 & 186 & 25,1 & 211 & 28,4 & 227 & 30,6 & 75 & 10,1 & 3,14 & 1,08 \\
\hline $\begin{array}{l}\text { Google+ eri- } \\
\text { șimi }\end{array}$ & 99 & 25,6 & 65 & 5 & 44 & 5,9 & 169 & 22,8 & 184 & 24,8 & 254 & 34,2 & 91 & 12,3 & 3,24 & 1,11 \\
\hline Twitter erişimi & 206 & 53,4 & 44 & 8 & 51 & 6,9 & 195 & 26,3 & 210 & 28,3 & 219 & 29,5 & 67 & 9,0 & 3,07 & 1,09 \\
\hline $\begin{array}{l}\text { Linkedin eri- } \\
\text { şimi }\end{array}$ & 33 & 8,5 & & 10 & 59 & 8,0 & 218 & 29,4 & 236 & 31,8 & 179 & 24,1 & 50 & 6,7 & 2,92 & 1,05 \\
\hline $\begin{array}{l}\text { Instagram eri- } \\
\text { șimi }\end{array}$ & 83 & 21,5 & & 7 & 49 & 6,6 & 186 & 25,1 & 215 & 29,0 & 215 & 29,0 & 77 & 10,4 & 3,11 & 1,09 \\
\hline $\begin{array}{l}\text { Pinterest eri- } \\
\text { şimi }\end{array}$ & 26 & & 710 & 11 & 58 & 7,8 & 223 & 30,1 & 257 & 34,6 & 153 & 20,6 & 51 & 6,9 & 2,88 & 1,04 \\
\hline Blog erişimi & 34 & 8,8 & 8 & 9 & 56 & 7,5 & 190 & 25,6 & 246 & 33,2 & 183 & 24,7 & 67 & 9,0 & 3,02 & 1,08 \\
\hline $\begin{array}{l}\text { Mobil telefon- } \\
\text { larla uyumu }\end{array}$ & 210 & 54,4 & 43 & 1 & 4 & 0,5 & 24 & 3,2 & 31 & 4,2 & 300 & 40,4 & 383 & 51,6 & 4,39 & 0,76 \\
\hline $\begin{array}{l}\text { Kurumun Mo- } \\
\text { bil uygulaması }\end{array}$ & 12 & & 111 & 2 & 3 & 0,4 & 34 & 4,6 & 80 & 10,8 & 326 & 43,9 & 299 & 40,3 & 4,19 & 0,83 \\
\hline
\end{tabular}

Tablo 8 genel olarak incelendiğinde tüketicilerin sosyal medya araçlarından daha çok web sitelerine mobil cihazlardan erişime önem vermişlerdir. Web sitelerinin mobil cihazlarla uyumlu olması ve mobil cihazlardan erişim için kurumun mobil uygulamasının olması tüketici değerlendirmesinde çok önemli olarak görülürken, mevcut durumda bu iki bileşenin özellikle kurumun mobil uygulaması bileşeninin yeteri kadar kullanılmadığı görülmüştür. Sosyal medya araçların Facebook mevcut durum ve tüketici değerlendirmesi karşılaştırılmasında en önemli olarak görülürken, fotoğraf paylaşım uygulaması olan Pinterest önem sıralaması en düşük bileşen olarak görülmektedir. 
Tablo 9. Güvenlik Bileşenlerine İlişkin Mevcut Durum İle Tüketici Değerlerinin Karşılaştırılması

\begin{tabular}{|c|c|c|c|c|c|c|c|c|c|c|c|c|c|c|c|}
\hline \multirow{3}{*}{ Güvenlik } & \multirow{2}{*}{\multicolumn{2}{|c|}{$\begin{array}{l}\text { Mevcut } \\
\text { Durum } \\
\text { "Var" } \\
(n=386)\end{array}$}} & \multirow{2}{*}{$\begin{array}{l}\mathrm{S} \\
\mathrm{I} \\
\mathrm{R} \\
\mathbf{A} \\
\mathrm{L} \\
\mathbf{A} \\
\mathbf{M} \\
\mathbf{A}\end{array}$} & \multicolumn{10}{|c|}{$\begin{array}{l}\text { Tüketicilerin Değerlendirmesi } \\
\qquad(n=742)\end{array}$} & \multirow{3}{*}{$\bar{X}$} & \multirow{3}{*}{ s.s. } \\
\hline & & & & \multicolumn{2}{|c|}{ 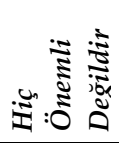 } & \multicolumn{2}{|c|}{ 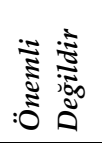 } & 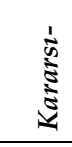 & \multirow{2}{*}{$\frac{\$}{\%}$} & \multicolumn{2}{|c|}{ 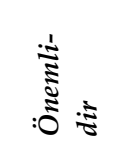 } & \multicolumn{2}{|c|}{ 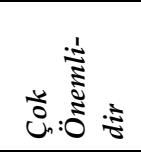 } & & \\
\hline & $\mathrm{f}$ & $\%$ & $\leftarrow \rightarrow$ & $\mathrm{f}$ & $\%$ & $\mathrm{f}$ & $\%$ & $\mathrm{f}$ & & $\mathrm{f}$ & $\%$ & $\mathrm{f}$ & $\%$ & & \\
\hline $\begin{array}{l}\text { Güvenlik } \\
\text { veya gizlilik } \\
\text { bilgisi }\end{array}$ & 126 & 32,6 & 42 & 1 & 0,1 & 2 & 0,3 & 23 & 3,1 & 152 & 20,5 & 564 & 76,0 & 4,71 & 0,54 \\
\hline $\begin{array}{l}\text { Çevrimiçi } \\
\text { alışveriş } \\
\text { imkânı }\end{array}$ & 128 & 33,2 & 34 & 3 & 0,4 & 28 & 3,8 & 50 & 6,7 & 233 & 21,4 & 428 & 57,7 & 4,42 & 0,80 \\
\hline $\begin{array}{l}\text { Güvenlik } \\
\text { ibaresi }\end{array}$ & 102 & 26,4 & 51 & 2 & 0,3 & 2 & 0,3 & 18 & 2,4 & 118 & 15,9 & 602 & 81,1 & 4,77 & 0,52 \\
\hline $\begin{array}{l}\text { Elektronik } \\
\text { sözleşme su- } \\
\text { numu }\end{array}$ & 95 & 24,6 & 63 & 2 & 0,3 & 4 & 0,5 & 19 & 2,6 & 188 & 25,3 & 529 & 71,3 & 4,66 & 0,58 \\
\hline $\begin{array}{l}\text { TÜRSAB lo- } \\
\text { gosu }\end{array}$ & 211 & 54,7 & 15 & 11 & 1,5 & 11 & $1,5 \&$ & $\begin{array}{ll}88 & 1\end{array}$ & 11,9 & 199 & 26,8 & 433 & 58,4 & 4,39 & 0,86 \\
\hline $\begin{array}{l}\text { TÜRSAB } \\
\text { belge numa- } \\
\text { rasi }\end{array}$ & 139 & 36,0 & 26 & 12 & 1,6 & 15 & 2,0 & $93 \quad 1$ & 12,5 & 215 & 29,0 & 407 & 54,9 & 4,33 & 0,88 \\
\hline
\end{tabular}

Tablo 9'da güvenlik bileşenlerine ilişkin mevcut durum ile tüketici değerlerinin karşılaştırılması gösterilmiştir. Buna göre seyahat acenteleri web sitelerinin $\% 54,7^{\prime}$ sinde güvenlik bileşenleri içinde işletmelerce en çok yer verilen özelliğin TÜRSAB logosu olduğu, bu bileşenin web sitelerinde olması tüketiciler tarafından da çok önemli $(\bar{X}=4,39)$ olarak değerlendirildiği görülmektedir. Güvenlik ölçeği bileşenleri tüketicilerin önceliğine göre sıralandığında ise çevrimiçi ödemede güvenlik ibaresi $(\bar{X}=4,77)$ bileşeni ilk sırada yer almaktadır. Bu bileşenin mevcut durum ile karşılaştırılmasında güvenlik ibaresinin web sitelerin \%26,4'ünde ve sıralama yönünden beşinci sırada yer aldığı görülmektedir. TÜRSAB belge numarası bileşeninin karşılaştırılmasına bakıldığında mevcut durumda web sitelerin \%36'sında yer aldığı görülürken, tüketicilerin değerlendirmesinde çok önemli ( $\bar{X}=4,33$ ) olan bu bileşenin güvenlik ölçeği altında son sırada ol- 
duğu görülmektedir. Güvenlik bileşenlerinin mevcut durumunda son s1rada yer alan satın almadan önce elektronik sözleşme sunumu web sitelerin sadece \%24,6'sında görülürken, tüketicilerin önem düzeyi sıralamasinda bu bileşen çok önemli ( $\bar{X}=4,66)$ olarak üçüncü sırada yer almaktadir.

Tablo 9 genel olarak incelendiğinde güvenlik başlığ bütün bileşenlerin tüketiciler tarafından önemli bulunduğu görülmektedir. Bununla birlikte web sitelerinde tüketiciler tarafından yer alınması istenen güvenlik ibaresi ve güvenlik veya gizlilik bilgisi bileşenleri seyahat acenteleri web sitelerinde yeterli düzeyde olmadığı görülmektedir.

\section{Sonuç ve Öneriler}

Teknolojinin getirdiği alışkanlıklar arasına giren internet ve web sitesi kullanımı ilerleyen yıllarda da insan yaşamı içerisindeki etkisini arttıracağı düşünüldügünde her yaştan internet kullanıcısını bir şekilde çevrimiçi ortamlarda turizm ile buluşturması öngörülebilir. Seyahat acenteleri de bu gelişimi takip ederek e-ticaretten gelecek olan payını arttırmak için web sitelerini tüketicilerinin istek ve ihtiyaçları doğrultusunda güncelleme yoluna gitmelidir.

Söz konusu bu çalışma ile Türkiye'de yer alan A grubu seyahat acenteleri web sitelerinin mevcut durumunu incelemek, seyahat acenteleri web sitelerinin turizm pazarındaki öneminin anlaşılması ve web sitelerinin daha etkin bir konuma gelebilmesi için yeni dijital odaklı pazarlama stratejilerinin geliştirilmesi önerilmektedir.

Araştırmanın sonucunda görsel tanıtım bileşenleri altında yer verilen "logo" ve "kurumun hakkımızda" sayfasının web sitelerinde yaygın bir şekilde kullanıldığ görülmektedir. Bunun yanında seyahat acentelerinin kurumsal kimliklerini yansitan vizyon, misyon ve slogan gibi diğer özelliklerinin ise çoğunlukla kullanılmadığ görülürken tüketiciler açısından bakıldığında bu özelliklerin web sitelerinde daha yaygın şekilde kullanılması gerektiği görülmektedir. Buna bağlı olarak tüketicilerin kurumsal olarak gözüken web sitelerine daha çok önem verdiği söylenebilecektir.

Görsel uyumluluk ve bütünlük başlı̆̆ı altında yer alan araştırma bulguları incelendiğinde seyahat acenteleri web sitelerinde görsel zenginliğin 
yaygın bir şekilde kullanıldığg ve tüketicilerinde bu özelliklere önem verdiği görülmektedir. Web sitesine girildiğinde arka planda çalan bir müziğin olması ya da menü girişlerinde sesli bir uyarının olması hem mevcut kullanımda yaygın olmayan bir özellik olarak hem de tüketici değerlendirmesinde daha az önemli bir bileşen olarak değerlendirilmektedir. Bunun yanında tüketicilerin web sitelerinin açılış hızına oldukça önem verdikleri görülmektedir. Bu durumun web sitelerinin tasarlanmasında en önemli hususlardan birisi olarak değerlendirilmesi doğru olacaktır.

Araştırma bulgularına göre, seyahat acentelerinde web sitelerinde yer alan ürünlerin özelliklerinin belirtilmesi yaygın bir şekilde kullanılırken, aynı ürünlere ait fiyat, kampanya ve indirim bilgilerinin daha az kullanıldığ 1 görülmüştür. Tüketici değerlendirmelerine göre ise web sitelerinde yer alan ürünlerin fiyat, kampanya ve indirim bilgilerinin olması daha önemli olarak görülmektedir. Bununla birlikte tüketiciler tarafından önemli olan kullanıcı tecrübelerine ait yorumların, seyahat acenteleri tarafından yaygın bir şekilde kullanılmadığı görülmektedir. Oysa çevrimiçi tüketici değerlendirmeleri seyahat edenlerin kararlarını önemli bir şekilde etkilemektedir (Ye, Law ve Gu, 2009, ss.180-182).

Seyahat acenteleri web sitelerinde iletişim sayfalarının ve genellikle bu sayfa içeriğinde yer verilen müşteri geri bildirim formunun yaygın bir şekilde kullanıldığı görülmektedir. Tüketiciler tarafından en çok öneme sahip olan kurumun çağrı hizmetlerinin web sitelerinin ana sayfasında yer almasının seyahat acenteleri tarafından daha az kullanıldığı görülmektedir. Müşteri desteği ve hizmetleri başlığı altında tüketiciler tarafından web sitesinde yer almasının çok önemli olduğu düşünülen SSS menüsü ve çevrimiçi mesajlaşmaya seyahat acenteleri tarafından web sitelerinde çok az yer verildiği görülmektedir. Yardım menüsü, güncel döviz kuru ve döviz çevirici bileşenleri ise seyahat acenteleri web sitelerinde yaygın bir özellik olarak karşımıza çıkmamaktadır. Bu durum seyahat acentelerince müşteri ilişkileri yönetimi bağlamında tüketicilerin beklentilerinin tam olarak anlaşılmadığını göstermektedir.

Araştırmanın sonuçlarına göre web sitelerinde kullanılan sosyal medya araçlarının tüketicilerin değerlendirmesiyle yakınlık gösterdiği görülmektedir. Web sitelerinin çoğunluğunda en az bir tane sosyal medya erişimi görülmektedir. Tüketicilerin değerlendirmesinde en yaygın olarak kullanılması gerekilen özelliklerin web sitelerinin mobil telefonlarla 
uyumu ve kurumun mobil uygulamasının olması olarak görülmektedir. $\mathrm{Bu}$ özelliklerin web sitelerinde kullanım açısından elde edilen bulgulara göre mobil telefonlarla uyumlu olarak görülen web sitelerinin, mobil uygulamasının çok az olduğu görülmektedir.

Turizm sektöründe mobil uygulamaların ve sosyal medyanın öneminin her geçen gün arttı̆g bir dönemde (Sun, Fong, Law ve He, 2017, s.366) bu unsurların kullanımının yaygınlaştırılması fayda sağlayacaktır. Bir diğer sonuca göre seyahat acenteleri web sitelerinde tüketiciler için önemli olan güvenlik ibaresi, güvenlik veya gizlilik bilgisi, elektronik sözleşme sunumu gibi özelliklerin yaygın bir şekilde kullanılmadığı görülmüştür. Benzer şekilde TÜRSAB tarafından kullanılması gereken TÜRSAB logosu web sitelerin yarıdan fazlasında yer alırken belge numarasının yaygin bir şekilde kullanılmadığı görülmektedir. Ayrıca seyahat acenteleri web sitelerinde çevrimiçi alışveriş imkânın az olması web sitelerin pazarlama amacından çok bilgi sunma amaçlı olduğunu da göstermektedir. Bu durum çevrimiçi satın alım yapmak isteyen tüketicilerin başka dağıtım kanallarına yönelmelerine neden olabilecektir.

Sonuç olarak, ülkemizde faaliyet gösteren seyahat acenteleri web sitelerinin çağdaş bilgi ve iletişim teknolojilerinden yeterli ölçüde faydalanmamakla birlikte bir gelişim sürecinde oldukları görülmektedir. Geleneksel anlayıştan vazgeçip ya da geleneksel anlayışla beraber modern pazarlama anlayışını da beraberinde kullanan seyahat acenteleri özellikle web siteleri üzerinden erişebilecekleri tanıtım, pazarlama ve müşteri potansiyeli arttırma gibi imkânları verimli kullanamamaktadır. Araştırma kapsamında incelenen web sitelerinin çok az bir kısmı bu avantajlardan profesyonel olarak yararlanırken, büyük bir kısmı sadece bilgi amaçlı olarak web sitelerini kullanmaktadır. Dolayısıyla bu araştırma kapsamında değerlendirilen seyahat acentelerinin çoğunluğunun işbirlikçi bir yapıyı temsil eden Web 1.0'dan Web 2.0 geçişini (Buhalis ve Law, 2008; Sigala, 2017) henüz tamamlayamadıkları söylenebilecektir. Ayrıca seyahat acenteleri tüketicilerin beklentilerini tam olarak anlayamadıkları, web sitelerinin tüketici beklentileri ile örtüşmediği de görülmektedir. Tüketicilerin seyahat acenteleri web sitelerinde bulunmasını istediği ve önem verdiği bileşenlerden yoksun olması seyahat acentelerinin çevrimiçi itibarlarını olumsuz yönde etkileyeceği gibi, çevrimiçi seyahat pazarından daha az pay almalarına neden olacaktır. 
Teknolojik cihazların ve özellikle internetin gelişimine paralel olarak tüketiciler artık istedikleri hizmet ve ürüne en hızlı ve kolay yoldan ulaşma eğilimine doğru gitmektedir. Web siteleri de bu gelişim ağı içerisinde tüketicisine en hızlı, kolay ve etkili yoldan ulaşmayı amaçlamalıdır. Seyahat acentelerinin sanal ortamdaki vitrini olan web sitelerini geliştirmeleri müşteri profilinin yanında ticaret hacmini arttırmaları için de fırsatlar sunabilmektedir. Bu bağlamda araştırma bulgularını temelde web sitelerinin daha etkili ve günümüz şartlarına daha uygun olmasını sağlayabilecek bazı öneriler şu şekilde sıralanmıştır:

- E-ticaretten daha çok bilgilendirme amaçlı açılan seyahat acenteleri web siteleri e-ticarete uygun hale getirilip, hem satış hacmini hem de müşteri sayısı arttırılabilir.

- Seyahat acentelerinin müşterilerine sunduğu ürünlerin sadece bilgi amaçlı olmayıp, fiyatlarının net bir şekilde belirtilmesi ürün satışını gerçekleştirmese dahi acentenin tüketicisini memnun edebilir.

- Çevrimiçi satış yapan seyahat acenteleri web sitelerinde güvenli ödeme, güvenli alışveriş ibarelerini, TÜRSAB logo ve belge numarasının daha belirgin ve net bir şekilde kullanılması seyahat acentesinin "güven fonksiyonunun" tüketici gözünde daha anlaşılır olmasını sağlayabilir.

- Web sitesinin genel temasına daha uygun, içeriğini daha net ve belirgin şekilde yansıtan ve ana sayfanın kullanışlı bir yerinde konumlandırılmış yönlendirme menüsü web sitesini daha çekici göstereceği gibi diğer sayfalarının gezinti oranını da arttırabilir.

- Seyahat acentelerinin müşterilerinin beklentilerini, istek ve ihtiyaçlarını daha iyi anlamaları için müşteri hizmetleri fonksiyonunu geliştirmelidir. Çağrı hizmetleri numarasının ana sayfada net bir şekilde görülmesi, çevrimiçi mesajlaşma imkânının olması, kullanıcı tecrübelerine ve yorumlarına kendi web sitesi bünyesinde yer vermesi, sunulan ürünlerin renkli ve net fotoğraflarla ayrıca çoklu ortam araçlariyla desteklenmesi web sitesini ziyaret eden müşterilerinin memnuniyeti arttırmada büyük rol oynayabilecektir.

- Sosyal medya platformlarının web sitelerinde sadece erişim olarak gösterilmesinden çok özellikle araştırmada ilk beş sırada yer 
alan sosyal medya platformlarını aktif bir şekilde kullanmak seyahat acentesinin sunduğu hizmet ve ürünleri çok daha ayrıntılı, hızlı ve kolay yoldan daha çok müşteri ile buluşturmasına olanak sağlayabilecektir.

- Günümüz tüketicilerinin bilgiye ve sunulan ürüne erişim imkânlarının gelişmesiyle özellikle seyahat acenteleri web sitelerinin mobil cihazlarla uyumlu olması ve mobil cihazlarda çalışan yazılımların geliştirilmesiyle tüketiciye daha hızlı ulaşmasını, doğrudan satış hacminin geliştirilmesini sağlayabilir.

- Seyahat acenteleri web sitelerinden yaptığı satışlar sonrasında müşterilerin ihtiyaç duyabileceği diğer ürün veya hizmetlerin tamamlayıcı bağlantılar ile desteklenmesi müşteri memnuniyetini arttıracaktır. Bu bağlamda özellikle paket tur satışı gerçekleştiren acentelerin otel tanıtımı yanında konaklamanın yapılacağı destinasyon hakkında bilgilere yer vermesi, yöresel yiyecek ve içeceklerden, destinasyona ait kültürel, sanatsal ve tarihi değerlerden, eğlence merkezleri ve yerel bilgilerden bahsedilmesi paket tura ya da acentenin ürünlerine olan ilgiyi arttırabilir.

- Araştırma sonuçlarına göre web sitelerinin açılış hızı ortalaması temel alınan açllış hızından daha yüksek bir değerde olduğu görülmüştür. Bu bağlamda web siteleri uzman kişilerden yardım alarak her geçen gün gelişen internet alt yapı hızına yetişmesi ve web sitesi ziyaret oranını arttırması kurumun yararına olacaktır.

İşletmeler gelişen teknolojiyi özellikle de internetin avantajlarını daha iyi kullanarak turizmden alınan payı artırma yoluna gitmelidirler. Bu bağlamda sadece bir web sitesi yapmak artık yeterli değildir. Web sitelerinde kullanılacak olan bileşenlerin seçilmesi için bu konuda uzman kişilerden yardım alınması çok daha etkin ve kaliteli bir iş ortaya çıkaracaktır. Ayrıca yapılan web sitelerin klasik pazarlama anlayışından çıarak çağdaş pazarlama anlayışı içerisinde yer alan müşterileri beklenti, istek ve ihtiyaçları etrafında şekillenmesi işletmenin sanal ortamdaki yüzü olan web sitelerini çok daha kullanışlı hale getirebilir.

Araştırmanın bulguları incelendiğinde seyahat acentelerinin büyük bir kısmı modern pazarlama anlayışından uzak web siteleri ile sanal ortamda yer almaktadır. Kurumun kültürünü yansıtan bir web sitesine sahip olma 
işletmeler için önemini her geçen gün arttırmaktadır. Bu bağlamda yapılacak olan web sitelerinin daha profesyonel, bilgi içerikli ve satış odaklı olması, bunun yanında tüketicisine sunduğu güvenin net bir şekilde anlaşılması seyahat acentelerinin kurumsallığını arttırabilir. Görsellik öğelerinin yeterince kullanıldığ 1 web sitelerinin ise güvenlik ve çevrim içi satış özelliklerinin geliştirilmesi ile işletmenin satışlarını ve pazar payını arttırabilir.

Bu alanda yapılacak olan yeni araştırmalar başta seyahat acenteleri olmak üzere, web sitesine sahip turizm sektöründeki işletmeler için yol gösterebilir, interneti daha etkin ve verimli kullanarak işletmelerin daha büyük pazara sahip olması, kurumsallığını arttırması, müşteri potansiyelini ve profilini genişletmesi, yeni dijital odaklı pazarlama stratejileri geliştirebilmesi konularında yardımcı olacaktır. Ayrıca buna benzer çalışmaların artması ile web sitelerinin tamamen tüketiciler üzerindeki etkisi incelenebilir böylelikle tüketicilerin istek ve ihtiyaçlarını daha iyi anlama konusunda daha iyi sonuçlar elde edilebilir. 
EXTENDED ABSTRACT

\title{
Descriptive Analysis and Consumer Evaluation of Travel Agencies Websites
}

\author{
Mehmet Yalçın - Ozan Bahar \\ Pamukkale University - Muğla University
}

The impact of developments in technology on communication channels brings new trends in marketing. Especially with the increase of internet usage, electronic marketing is a comprehensive concept that is formed in this new marketing trend. The internet, which provides relational and interactive marketing with the consumer, meets the products and services of the enterprises in a single platform with the consumer. At the same time, the consumer is not only interested in buying the product, but also to obtain information from the Internet and to examine the product in order to make the purchase decision. Travel agencies, which have dynamic structure and continuous interactive business understanding, have to follow their consumers closely and try to keep up with these innovations and support the provision of various services on the web Therefore, from the design of the websites to the presentation of the needs, demands and demands of the consumers, it is a necessary indicator for the competition.

This study aims to reveal the current usage status of the travel agencies web sites that have become the virtual showcase of the enterprises with the development of internet and communication tools, The evaluation of the components used in the websites from a consumer point of view and the comparison of consumer assessments and the current situation. However, it is aimed to reach the results of travel agencies in the tourism market and what consumers expect from a website.

\section{Method}

In this study, descriptive analysis was used as the first stage of the research in order to examine the content of the websites. In this context, 47 
web site evaluation components were formed under 6 main headings and 386 websites were evaluated with descriptive analysis with this scale. Visual presentation (corporate identity), visual compatibility and integrity, information presentation, customer support and services, social media traceability and mobile use and security are the six main criteria. In the second phase of the study, an online survey was conducted with 742 academicians. In the last phase, the current situation and the expectations of consumers were compared.

\section{Findings, Discussion and Results}

According to the findings of the research, it is seen that the websites of travel agencies are inadequate for online shopping and used for informing function rather than marketing activities. Travel agencies can offer many opportunities such as increasing the online trading volume with the customer profile by improving the web sites that are showcase in the virtual environment according to today's consumer needs. When the findings are examined, it is seen that travel agencies give the most importance to the "logo", but consumers care "about us page". It is seen that the photos on the main page are the most common component of the visual compliance and integrity of travel agencies websites. When the importance level is examined by consumers, it is seen that the component that takes the first place is useful routing menus. While the most commonly used component of the products offered by the web sites of travel agencies is to specify the characteristics of the products, The most desirable feature of consumers is the price of the products. It is seen that travel agencies have a separate contact page for all of the websites for customer support. Consumers stated that the most number of call services under this heading should be on the main page. In the title of social media traceability, $65 \%$ of the websites examined have at least one social media access button. The most widely used social media platform is facebook. For consumers, the most important feature is the mobile compatibility of websites. As for security features, it is important to have TÜRSAB logo on travel agencies web sites. When examined as consumers, the security phrase was found to be important on the websites. 
As a result, the travel agency website showing activity in Turkey to benefit sufficiently from modern information and communication technology is seen that in the development process together. Furthermore, a plan must be made in accordance with the expectations and wishes of the consumers before a website is made. In order to increase the share of ecommerce from travel agencies, travel agencies should update their websites in line with their expectations and requests.

\section{Kaynakça / References}

Ainscough, T., L. (1996). The internet for the rest of us: Marketing on the world wide web. Journal Of Consumer Marketing, 13(2), 36-47.

Akar, E. (2010). Güncel pazarlama yaklaşımlarından seçmeler. Ankara: Detay Yayıncilik.

Arıkan, İ. ve Ahipaşaoğlu S. (2005). Ulaştırma işletmeleri, 2. Baskı, Ankara: Gazi Kitabevi

Bahar, O. ve Kozak, M. (2008). Turizm ekonomisi. Ankara: Detay Yayıncılık. Bayram, M. ve Yaylı, A. (2009). Otel web sitelerinin içerik analizi yöntemiyle değerlendirilmesi. Elektronik Sosyal Bilimler Dergisi, 8(27), 347-379.

Bevanda, V., Grzinic, J.,ve Cervar, E. (2008). Analysing the users' perceptions of web design quality by data mining tools. Tourism and Hospitality Management, 14(2), 251-262.

Buhalis, D. (1998). Strategic use of information tecnologies in the tourism industry. Tourism Management, 19(5), 409-421.

Buhalis, D., ve Law, R. (2008). Progress in information technology and tourism management: 20 years on and 10 years after the internetthe state of etourism research. Tourism management, 29(4), 609-623.

Chan, S. ve Law, R. (2006). Automatic website evaluations: the case of hotels in Hong Kong. Information Technology ve Tourism, 8(3), 255-269.

Cheung, W. M. ve Huang, W. (2002). An investigation of commercial usage of the World Wide Web: a picture from Singapore. International Journal of Information Management, 22, 377-388.

Cox, J. ve Dale, B.G. (2002). Key quality factors in web site design and use, an examination. International Journal of Quality ve Reliability Management, 19 (7), 862-888. 
December, J. (1994). Challenges for web information providers. ComputerMediated Communication Magazine, 1(6), 8-14.

Dündar S., Ecer F., Özdemir Ş. (2007). Fuzzy Topsis yöntemi ile sanal mağazaların web sitelerinin değerlendirilmesi. Atatürk Üniversitesi İktisadi ve İdari Bilimler Dergisi, 21(1),1-19.

Kaynama, S. A., ve Black, C. I. (2000). A proposal to assess the service quality of online travel agencies: An exploratory study. Journal of professional services marketing, 21(1), 63-88.

Law, R., Qi, S., ve Buhalis, D. (2010). Progress in tourism management: A review of website evaluation in tourism research. Tourism management, 31(3), 297-313.

Liu, Z., ve Huang, X. (2005). Evaluating the credibility of scholarly information on the web: A cross cultural study. ScienceDirect, 37(2), 99106.

Marsico, M. ve Levialdi, S. (2004). Evaluating web sites: Exploiting user's expectations. Int. J. Human-Computer Studies, 60, 381-416.

Öğüt, A., Güleş, H. K., Çetinkaya, A. Ş. (2003). Bilişim teknolojileri ışı̆̆ında turizm işletmelerinde yönetim enformatik bir bakış. Ankara: Nobel Dağitım.

Park, Y. A., Gretzel, U. ve Sirakaya, E. (2007). Measuring web site quality for online travel agencies. Journal of Travel ve Tourism Marketing, 23(1), 15-30.

Perdue, R. (2001). Internet site evaluations: The influence of behavioral experience, existing images, and selected website characteristics. Journal of Travel ve Tourism Marketing, 11(2/3), 21-37.

Roney, S. A., ve Özturan, M. (2006). A content analysis of the web sites of Turkish travel agencies. Anatolia, 17(1), 43-54.

Sigala, M. (2017). Collaborative commerce in tourism: Implications for research and industry. Current Issues in Tourism, 20(4), 346-355.

Sun, P., Cárdenas, D. A., ve Harrill, R. (2016). Chinese customers' evaluation of travel website quality: A decision-tree analysis. Journal of Hospitality Marketing ve Management, 25(4), 476-497.

Sun, S., Sun, S., Fong, D. K. C., Fong, D. K. C., Law, R., Law, R., ve He, S. (2017). An updated comprehensive review of website evaluation studies in hospitality and tourism. International Journal of Contemporary Hospitality Management, 29(1), 355-373. 
Stienmetz, J. L., Levy, S. E., ve Boo, S. (2013). Factors influencing the usability of mobile destination management organization websites. Journal of travel Research, 52(4), 453-464.

Tsang, N. K. F., Lai, M. T. H. ve Law, R. (2010). Measuring e-service quality for online travel agencies. Journal of Travel ve Tourism Marketing, 27(3), 306-323.

Webster, F. E. Jr, (1996). The future of interactive marketing. Harvard Business Review, 6, 153-157.

Ye, Q., Law, R., ve Gu, B. (2009). The impact of online user reviews on hotel room sales. International Journal of Hospitality Management, 28, 180-182.

Zafiropoulos, C. ve Vrana, V. (2006). A framework for evaluation of hotel websites: The case of Greece. Information Technology ve Tourism, 8(3/4), 239-254.

Zviran, M., C. Glezer, ve I. Avni (2006). User satisfaction from commercial web sites: The effect of design and use. Information and Management , 43 (2), 157-178.

Internet World stats, 2018, https://www.internetworldstats.com/stats.htm, e.t: 01.02.2019.

\section{Kaynakça Bilgisi / Citation Information}

Yalçın, M. ve Bahar, O. (2019). Seyahat acentelerinin web sitelerinin betimsel analizi ve tüketici değerlendirmesi. OPUS-Uluslararası Toplum Araştırmaları Dergisi, 11(18), 286-320. DOI: 10.26466/opus.522687 